\title{
Liberalização financeira, estabilidade macroeconômica e crescimento econômico nos países do BRIC
}

\author{
LUIZ FERNANDO DE PAULA \\ FÁBIO CAMPOS BARCELOS*
}

Financial liberalization, macroeconomic policy and economic growth within the BRIC's countries. The objective of this paper is to analyze the relationship between exchange rate regime, capital account convertibility and economic growth in 1990-2007 period within the emerging countries that constitute what has been called BRIC - Brazil, Russia, India and China. Our hypothesis is that economic performance of these countries is the result, at least partially, of the quality of the macroeconomic policy management adopted in each country, in which exchange rate policy, capital account convertibility and the degree of external vulnerability plays a key role.

Keywords: BRIC; financial liberalization; capital account convertibility. JEL Classification: E58; F31; F32; F34.

\section{INTRODUÇÃO}

Em outubro de 2003 um relatório da Goldman Sachs (Purushothaman e Wilson, 2003), usando projeções demográficas e um modelo de acumulação de capital e crescimento de produtividade, estimou para até 2050 o crescimento do PIB, da renda per-capita e as oscilações cambiais do BRIC (Brasil, Rússia, Índia e China). Tomando como base algumas premissas, o relatório previu que em menos de 40 anos os países do BRIC, juntos, poderiam possuir uma economia maior do que a

\footnotetext{
* Luiz Fernando de Paula é professor adjunto da Faculdade de Ciências Econômicas da Universidade do Estado do Rio de Janeiro (FCE/UERJ) e pesquisador do CNPq. E-mail: luizfpaula@terra.com.br; Fábio Campos Barcelos é técnico do Grupo de Memória da Administração Pública, do Arquivo Nacional. E-mail: fabio.barcelos@gmail.com. Submetido: 18/jun./2010; Aprovado: 20/maio/2008.
} 
do G6 e que em já 2025 a soma das suas riquezas equivaleria à metade da riqueza do G6. Apesar desse tipo de previsão ser suscetível a críticas, não podemos desconsiderar a importância e o potencial econômico do BRIC, graças às dimensões dos seus PIBs e suas proporções geográficas e populacionais, mesmo levando em consideração os problemas de desigualdade social desses países. Observando o desempenho econômico desde 1990, podemos verificar que o crescimento do PIB não foi similar entre os países do grupo: o crescimento médio, no período 1990-2007, na China, foi de $10 \%$; na Índia $6,4 \%$, no Brasil $2,5 \%$, e na Rússia $2 \%$. Considerando o período mais recente, entre 1999 e 2007, os números mudam significativamente no caso da Rússia: a China cresceu em média 9,7\%; a Índia 7,1\%; a Rússia $7 \%$; e o Brasil 3,1\%.

Por que o desempenho econômico e a estabilidade macroeconômica foram tão diferentes entre os países que compõem o chamado BRIC? Mais especificamente, em que sentido o regime de política macroeconômica e a gestão desta política foram responsáveis por estabelecer um ambiente que contribuiu para um maior (ou menor) desempenho econômico e estabilidade macroeconômica nesses países?

Este artigo busca analisar a relação entre regimes cambiais, conversibilidade da conta capital e crescimento econômico entre os países emergentes que constituem o BRIC durante o período a partir de quando liberalização da conta de capital passou a ser adotada, em menor ou maior grau, nesses países, isto é, desde o início da década de $1990^{1}$. A principal hipótese desenvolvida nesse trabalho é que o crescimento econômico do BRIC é resultado, ao menos parcialmente, da qualidade na gestão da política macroeconômica adotada em cada país, onde política cambial, conversibilidade da conta capital e o grau de vulnerabilidade externa têm um papel essencial. A metodologia adotada no artigo são estudos de caso, para então se efetuar uma comparação mais geral entre os países analisados.

O artigo é dividido em três seções, além desta Introdução. A segunda seção discute a relação entre conversibilidade da conta capital, regime cambial e estabilidade macroeconômica nos países em desenvolvimento. A terceira seção faz uma análise da experiência recente em cada um dos BRIC. A quarta seção realiza uma breve comparação dessas experiências e extrai algumas conclusões.

\section{REGIMES CAMBIAIS, CONTROLE DE CAPITAIS E ESTABILIDADE MACROECONÔMICA}

Uma discussão importante na literatura sobre questões macroeconômicas em países em desenvolvimento aborda qual seria o regime cambial mais apropriado para esses países. Por um lado, de acordo com a visão "bipolar", regimes intermediários são menos apropriados para que economias tenham um alto grau de inte-

\footnotetext{
${ }^{1}$ Cabe destacar que o artigo não objetiva analisar os efeitos da crise financeira internacional recente sobre os países do BRIC.
} 
ração com o mercado internacional de capitais. O principal argumento subjacente é que tais regimes intermediários tornam o país vulnerável a ataques especulativos (Fischer, 2001). Por outro lado, a visão chamada "fear of floating" aponta que, na prática, diversos países em desenvolvimento que adotaram regime de câmbio flutuante acabaram utilizando medidas para limitar o movimento da taxa de câmbio. Tal resistência a flutuações na moeda deriva da baixa credibilidade das suas políticas e instituições, e do alto grau de pass-through entre a taxa de câmbio e o índice interno de preços, entre outros fatores (Calvo e Reinhart, 2002). Outra razão para entender por que as autoridades monetárias evitam flutuações cambiais pode estar relacionada ao efeito que uma grande desvalorização cambial pode exercer no passivo externo dos bancos e empresas, quando esses possuem obrigações em moeda estrangeira. Além disso, flutuações na taxa de câmbio podem gerar incertezas que desfavorecem o comércio. Por exemplo, uma prolongada apreciação real, associada a uma maciça entrada de capitais, pode afetar negativamente a competitividade das exportações e os investimentos no setor externo (Bresser-Pereira e Gala, 2007).

Pode-se argumentar que a adoção de um regime de câmbio flutuante nos países em desenvolvimento é capaz de isolá-los de um ataque especulativo à moeda nacional, uma vez que a autoridade econômica não possui nenhum compromisso com a taxa de câmbio. Ademais, o câmbio flutuante é capaz de aumentar a autonomia sobre a política monetária, reiterando a ideia da "impossível trindade", que afirma que um país não pode ter, ao mesmo tempo, conversibilidade da conta capital, câmbio fixo e autonomia da política monetária. No entanto, o regime de câmbio flutuante no mundo real acaba funcionando de forma diferente à descrita nos livros-textos. Segundo Grenville (2000), os fundamentos econômicos não são capazes de explicar o comportamento da taxa de câmbio em um horizonte de curto/médio prazo, uma vez que esta pode apresentar grandes oscilações, sem que haja, nesses mesmos fundamentos, grandes mudanças capazes de explicá-las. De acordo com dados de Ho e McCauley (2003), apesar do rápido crescimento nos anos 1990, os mercados cambiais da maioria dos países em desenvolvimento continuam sendo menores e menos líquidos que os dos países desenvolvidos. Isso sugere que os mercados cambiais nos países emergentes são mais vulneráveis a apostas especulativas e instabilidade, uma vez que eles são estreitos e sujeitos a um alto grau de incerteza e assimetria de informação (Moreno, 2005, p. 10).

Uma certa flexibilidade na operação da taxas de câmbio flutuante pode ser útil na absorção do influxo de capital, no amortecimento de choques externos, e como resposta a mudanças na capacidade produtiva de economias emergentes; e ainda ajudar a inibir a entrada de capitais de curto prazo, servindo para alertar os tomadores de empréstimo em moeda estrangeira que a volatilidade da taxa de câmbio pode eliminar a vantagem da taxa de juros (Grenville, 2000, p. 59). Algum tipo de administração sobre o regime de câmbio flutuante pode ajudar quando o objetivo do banco central for diminuir a volatilidade cambial e também atuar sobre a taxa de câmbio real, dentro de um fim comercial. O banco central pode intervir no mercado cambial sempre que buscar um objetivo macroeconômico como controlar a 
inflação, manter a competitividade externa e/ou manter a estabilidade financeira. A intervenção das autoridades para limitar os movimentos da taxa de câmbio não significa necessariamente um compromisso com certo nível cambial, permitindo assim que a taxa de câmbio oscile para desincentivar o capital especulativo. Assim, a manutenção de uma taxa de câmbio real estável e competitiva pode ser um objetivo intermediário de longo prazo para uma política macroeconômica que objetiva alcançar um maior crescimento no nível de produto e de emprego (Frenkel, 2006).

Para aumentar a possibilidade de sucesso na gestão do regime cambial em economias emergentes, algumas medidas podem ser necessárias, visando reduzir tanto a volatilidade (e intensidade) na entrada de capitais como a oportunidade de ataques especulativos à moeda doméstica. Uma dessas medidas é a intervenção oficial no mercado cambial, que pode exercer influência sobre a taxa de câmbio nominal quando houver alteração na oferta relativa de ativos em moeda doméstica e estrangeira. De um lado, a habilidade de um país em resistir à desvalorização cambial é limitada pelas suas reservas em moeda estrangeira e por seu acesso potencial a linhas de crédito. $\mathrm{O}$ acúmulo de reservas cambiais pode ser visto como um seguro contra choques externos negativos e especulação sobre a moeda local, uma vez que países emergentes normalmente possuem acesso limitado ao mercado internacional de capitais. Por outro lado, a habilidade de acumular reservas e/ou de evitar a apreciação da moeda pode requerer o uso de operações esterilizadas. A política de acumulação de reservas requer algum tipo de financiamento doméstico devido ao excesso de moeda estrangeira em relação à moeda nacional em circulação. Se o banco central possui uma meta para o câmbio no curto prazo, então pode tentar compensar aumentos nas reservas bancárias vendendo títulos domésticos ou emitindo seus próprios títulos (Mohanty e Turner, 2006).

A avaliação da experiência recente de acumulação de reservas em países emergentes mostra que eles vêm obtendo sucesso na operação de esterilização, favorecido em parte pelo contexto de grande liquidez internacional (Mohanty e Scatigna, 2004). Os custos de manutenção têm sido baixos ou até mesmo negativos em alguns países importantes, como China, Coreia do Sul e Índia. Graças à eficiência das operações oficiais de intervenção no mercado de câmbio e ao ambiente de baixa inflação, a taxa de câmbio real não aumentou significativamente (em alguns casos até mesmo caiu) em muitos países com grandes e persistentes superávits nas suas contas correntes.

Uma outra possibilidade para melhorar a condução do regime cambial nos países em desenvolvimento é o uso de "técnicas de administração dos fluxos de capitais", que incluem "controle de capitais", isto é, normas que regulem o volume, a composição e/ou a alocação do capital internacional privado que entra no país, e/ou "regulamentações financeiras domésticas prudenciais", que se referem a questões de política, tais como regras de adequação do capital, necessidade de autorizações, restrições sobre os termos que instituições financeiras nacionais podem oferecer a certos tipos de projetos etc. (Epstein et al., 2003, pp. 6-7). Controles de capitais podem ser usados para diferentes objetivos não excludentes, como: (a) reduzir a vulnerabilidade do país a crises externas; (b) estabelecer uma "cunha" 
entre as taxas de juros internas e externas, provendo à política monetária uma maior autonomia para propósitos domésticos; e (c) assegurar uma maior estabilidade da taxa de câmbio no curto prazo, reduzindo as pressões derivadas de uma excessiva entrada de capitais. Segundo Ho e McCauley (2003, p. 34), “a experiência recente tem mostrando que controles de capitais, se bem desenhados e aplicados, podem ser úteis em proteger a economia contra aspectos desestabilizadores dos fluxos de capitais, dando suporte a implementação de outras políticas e mesmo resolvendo certos tipos de dilemas de política”.

\section{A EXPERIÊNCIA RECENTE DO BRIC}

\section{Brasil}

Desde o começo dos anos 1980 a economia brasileira vem apresentando um crescimento baixo e volátil: entre 1981 e 2007 a média do crescimento do PIB foi de 2,4\%, contrastando com o crescimento médio de 7,1\% entre 1947 e 1980, durante o período de industrialização por substituição de importações (ISI). O baixo crescimento entre 1990 e 2007 foi resultado do fenômeno de alta inflação (até 1994), de uma elevada vulnerabilidade externa e também dos efeitos de uma elevada taxa de juros real. Como resultado, as taxas de investimento foram baixas durante anos. Mais recentemente, favorecido por um contexto internacional benigno - boom de commodities e abundância de liquidez no mercado financeiro internacional - e redução na taxa de juros, a economia brasileira teve um crescimento maior (média de 4,7\% em 2004-2007). Por outro lado, após três décadas de alta inflação, a combinação de desindexação da economia, brusca redução de impostos de importação, altas taxas de juros e apreciação da taxa de câmbio, no bojo do Plano Real, resultou em uma rápida queda no índice de preços: de $2.477 \%$ em 1993 para 1,7\% em 1998.

Tabela 1: Brasil - principais indicadores econômicos

\begin{tabular}{l|r|r|r|r|r|r|r|r|r|}
\hline & 1990 & 1991 & 1992 & 1993 & 1994 & 1995 & 1996 & 1997 & 1998 \\
\hline $\begin{array}{l}\text { Crescimento real } \\
\text { do PIB (\% a.a.) }\end{array}$ & $-4,3$ & 1,0 & $-0,5$ & 4,7 & 5,3 & 4,4 & 2,2 & 3,4 & 0,0 \\
$\begin{array}{l}\text { Formação bruta de } \\
\text { capital fixo (\%PIB) }\end{array}$ & 17,3 & 18,3 & 18,4 & 19,3 & 20,7 & 20,5 & 19,3 & 19,9 & 16,7 \\
$\begin{array}{l}\text { Inflação (\%a.a.) } \\
\text { Resultado fiscal (\%PIB) }\end{array}$ & $-30,2$ & $-26,5$ & $-44,3$ & $-59,6$ & $-24,7$ & $-6,6$ & $-5,3$ & $-5,5$ & $-7,0$ \\
$\begin{array}{l}\text { Dívida pública (\%PIB)* } \\
\text { Taxa de câmbio - média }\end{array}$ & n.d. & 38,1 & 37,1 & 32,6 & 30,0 & 28,0 & 30,7 & 31,8 & 38,9 \\
(R\$/US\$) & 0,0 & 0,0 & 0,0 & 0,0 & 0,64 & 0,92 & 1,01 & 1,08 & 1,16 \\
$\begin{array}{l}\text { Reservas cambiais } \\
\text { (excl. ouro, US\$ milhões) }\end{array}$ & 7.441 & 8.033 & 22.521 & 30.604 & 37.070 & 49.708 & 58.323 & 50.827 & 42.580 \\
\hline
\end{tabular}

continua na página 704 


\begin{tabular}{|c|c|c|c|c|c|c|c|c|c|}
\hline Conta-corrente (\%PIB) & $-0,8$ & $-0,3$ & 1,6 & $-0,2$ & $-0,3$ & $-2,4$ & $-2,8$ & $-3,5$ & $-4,0$ \\
\hline $\begin{array}{l}\text { Reservas cambiais } \\
\text { (\% importações) }\end{array}$ & 36,0 & 38,2 & 109,6 & 121,0 & 111,5 & 100,1 & 109,4 & 84,9 & 73,7 \\
\hline Dívida externa (\%PIB) & 26,3 & 30,5 & 35,1 & 33,9 & 27,3 & 20,7 & 21,4 & 23,0 & 28,6 \\
\hline $\begin{array}{l}\text { Dívida externa/ } \\
\text { exportações }\end{array}$ & 3,9 & 3,9 & 3,8 & 3,7 & 3,4 & 3,4 & 3,8 & 3,8 & 4,7 \\
\hline $\begin{array}{l}\text { Balança comercial } \\
\text { (US\$ milhões) }\end{array}$ & 10.747 & 10.578 & 15.239 & 14.329 & 10.861 & -3.157 & -5.453 & -6.652 & -6.603 \\
\hline $\begin{array}{l}\text { Conta-corrente } \\
\text { (US\$ milhões) }\end{array}$ & -3.823 & -1.450 & 6.089 & 20 & -1.153 & -18.136 & -23.248 & -30.491 & -33.829 \\
\hline $\begin{array}{l}\text { Crescimento real } \\
\text { do PIB (\% a.a.) }\end{array}$ & 0,3 & 4,3 & 1,3 & 2,7 & 1,1 & 5,7 & 3,2 & 4,0 & 5,7 \\
\hline $\begin{array}{l}\text { Formação bruta } \\
\text { de capital fixo (\%PIB) }\end{array}$ & 15,6 & 14,1 & 17,0 & 16,4 & 15,3 & 16,1 & 15,9 & 16,4 & 17,5 \\
\hline Inflação (\%a.a.) & 8,9 & 6,0 & 7,7 & 12,5 & 9,3 & 7,6 & 5,7 & 3,1 & 4,5 \\
\hline Resultado fiscal (\%PIB) & $-5,3$ & $-3,4$ & $-3,3$ & $-4,4$ & $-4,7$ & $-2,8$ & $-3,4$ & $-3,5$ & $-2,8$ \\
\hline Dívida pública (\%PIB)* & 44,5 & 45,5 & 48,4 & 50,5 & 52,4 & 47,0 & 46,5 & 44,0 & 42,0 \\
\hline $\begin{array}{l}\text { Taxa de câmbio - média } \\
\text { (R\$/US\$) }\end{array}$ & 1,81 & 1,83 & 2,35 & 2,92 & 3,08 & 2,93 & 2,43 & 2,18 & 1,95 \\
\hline $\begin{array}{l}\text { Reservas cambiais (excl. } \\
\text { ouro, US } \$ \text { milhões) }\end{array}$ & 5.279 & 32.434 & 35.563 & 37.462 & 48.847 & 52.462 & 53.245 & 85.561 & 179.433 \\
\hline Conta-corrente (\%PIB) & $-4,3$ & $-3,8$ & $-4,2$ & $-1,5$ & 0,8 & 1,8 & 1,6 & 1,3 & 0,1 \\
\hline $\begin{array}{l}\text { Reservas cambiais } \\
\text { (\% importações) }\end{array}$ & 71,6 & 58,1 & 64,0 & 79,3 & 101,2 & 83,5 & 72,3 & 93,2 & 148,8 \\
\hline Dívida externa (\%PIB) & 41,2 & 36,6 & 40,8 & 45,1 & 42,5 & 33,2 & 21,3 & 18,6 & 18,3 \\
\hline $\begin{array}{l}\text { Dívida externa/ } \\
\text { exportações }\end{array}$ & 5,0 & 4,3 & 3,9 & 3,8 & 3,2 & 2,3 & 1,6 & 1,4 & 1,5 \\
\hline $\begin{array}{l}\text { Balança comercial } \\
\text { (US\$ milhões) }\end{array}$ & -1.261 & -698 & 2.650 & 13.121 & 24.794 & 33.666 & 44.703 & 46.458 & 40.031 \\
\hline $\begin{array}{l}\text { Conta-corrente } \\
\text { (US\$ milhões) }\end{array}$ & -25.400 & -24.225 & -23.215 & -7.637 & 4.177 & 11.738 & 13.984 & 13.620 & 1.550 \\
\hline
\end{tabular}

Fonte: IMF - International Financial Statistics, e IPEADATA (crescimento do PIB, inflação, resultado fiscal, dívida pública e dívida externa).

OBS.: (*) Dezembro de cada ano.

Desde o começo da década de 1990 até os dias atuais, o Brasil apresentou diferentes estratégias em relação a sua política econômica: no período 1990-1994 a política era baseada em um regime de câmbio crawling-peg passivo, com desvalorizações nominais diárias, que levava a uma taxa de câmbio real depreciada ${ }^{2}$

\footnotetext{
${ }^{2} \mathrm{O}$ índice da taxa de câmbio real efetiva (TCRE) é definido como um índice de taxa nominal efetiva ajustada pela evolução dos preços no país e em países selecionados. A TCRE, no Brasil e em outros países latino-americanos, é calculada de forma diferente do convencional, ou seja, multiplicando a taxa de câmbio nominal pelo índice de preços do país local e dividindo pelo índice de preços do(s) seu(s) parceiro(s) comercial(ais), ponderados por suas participações no comércio do país em questão, enquanto, frequentemente (como no caso de China, Índia e Rússia), a TCRE é calculada multiplicandose a taxa nominal pelo índice de preços do parceiro comercial e dividindo-se pelo índice de preços
} 
(Figura 1), além de juros reais altos; tais políticas geraram superávits na balança comercial e atraíram capital de fora do país, ao custo de altos níveis internos de inflação. O período entre julho de 1994 e janeiro de 1999, quando vigorou o Plano Real, é caracterizado pelo uso de uma âncora nominal (uma taxa de câmbio que variava dentro de uma banda previamente definida) para fins de estabilização e a implementação de uma política monetária apertada, que resultou em uma grande sobrevalorização cambial e o consequente déficit comercial financiado por entrada de capitais. Esse período é também caracterizado pelo contágio de crises externas (crise mexicana, crise asiática e crise russa). Sob o contexto de uma taxa de câmbio semifixa, o Banco Central do Brasil (BCB) reagia ao movimento de saída de capitais, elevando fortemente a taxa de juros e ao mesmo tempo oferecendo aos agentes "hedge" contra a desvalorização da taxa de câmbio via emissão de títulos públicos indexados ao câmbio.

Após a crise cambial de janeiro de 1999, resultado entre outros fatores da elevada vulnerabilidade externa do país (déficit em conta-corrente de $4 \%$ do PIB em 1998), o Brasil adotou um novo modelo de política econômica, baseado nas seguintes características: regime de câmbio flutuante, sistema de metas de inflação e geração de constantes superávits primários ${ }^{3}$, que resultaram em taxas de juros menores que no período anterior (1995-1998), mas ainda altas, além de uma grande volatilidade na taxa de câmbio. O modus operandi do sistema de metas de inflação, somado ao regime de câmbio flutuante e operando sob condições de abertura (quase) total da conta de capital, resultou em grande instabilidade da taxa de câmbio nominal. A fuga de capitais gerada por pressões especulativas contra o real levou a uma desvalorização cambial que afetou os preços domésticos, o que frequentemente põe em xeque as metas inflacionárias estabelecidas pelo $\mathrm{BCB}$ - as metas fixadas não foram alcançadas de 2001 a 2003. Sob essas circunstâncias o $\mathrm{BCB}$ teve que elevar a taxa de juros para reduzir o efeito do pass-through - foi assim em 2001 com a crise que abalou os mercados internacionais e em 2002-2003 com a desconfiança dos mercados com relação à eleição do presidente Lula. A reação do $\mathrm{BCB}$ aos movimentos da taxa de câmbio resultou na redução do nível de produto e emprego, e ainda em um aumento no volume da dívida pública ${ }^{4}$.

domésticos. Como resultado, quando a TCRE no Brasil aumenta, indica uma desvalorização, e quando declina, uma valorização; nos outros países o raciocínio é o inverso.

${ }^{3}$ O superávit primário aumentou de 0\% do PIB em 1998 para 3,2\% em 2002, alcançando 4,4\% em 2003 e quase $5 \%$ em 2005 .

${ }^{4} \mathrm{O}$ crescimento da dívida pública em períodos de crise externa no Brasil no período analisado (superou 50\% do PIB em 2002-2003) ocorreu em função da existência de títulos públicos indexados a taxa Selic e a taxa de câmbio. Para uma análise da economia brasileira no pós-Real, ver Ferrari-Filho e Paula (2003). 
Figura 1: Brasil - taxa de câmbio real efetiva (jun/1994=100)

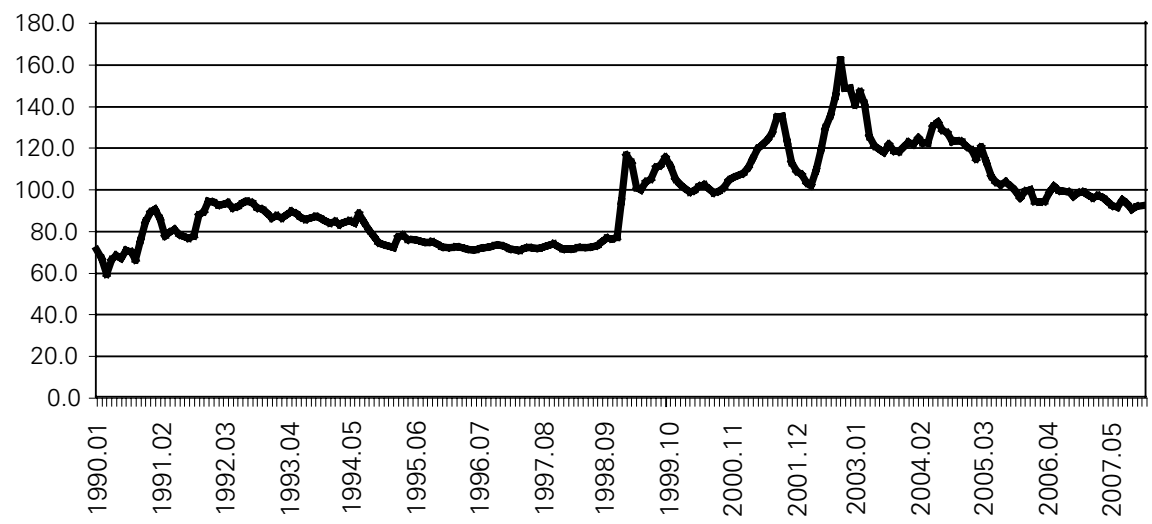

Fonte: IPEADATA

Na legislação sobre entrada e saída de capitais no Brasil, introduzida em 1960, o fluxo do capital estrangeiro deveria ser registrado para se obter permissão em saídas casadas (lucros, juros, royalties e dividendos). Desde o final da década de 1980 houve uma tendência crescente de liberalização da conta de capital no Brasil. Já no começo dos anos 1990, as proibições e entraves burocráticos que impediam investimentos diretos estrangeiros (IDE) foram eliminados. Em 1991, foi permitida a compra de ações de empresas nacionais por investidores estrangeiros. Em 1992 o BCB autorizou uma ampla liberalização em relação à saída de capitais, permitindo que uma conta especial não residente, chamada CC5, pudesse ser operada com mais liberdade por instituições financeiras estrangeiras nas operações de compra e venda de divisas. Essa exceção criou um caminho fácil para a saída de capital de curto prazo, que foi bastante usado durante períodos de ataque especulativo contra a moeda nacional e representou a introdução de uma conversibilidade de facto, já que na prática residentes podiam fazer depósitos em uma conta de um banco estrangeiro, operada em um banco no país, que poderia converter moeda nacional em moeda estrangeira (Goldfajn e Minella, 2005). Em abril de 1994 o Plano Brady converteu os empréstimos estrangeiros em títulos da dívida, ajudando a superar a crise da dívida externa que marcou os anos 1980. Ainda em 1994, o BCB implementou um imposto sobre a entrada de capitais e aumentou os requisitos mínimos de maturidade para a entrada de capital no país, visando amenizar a pressão sobre a taxa de câmbio, minimizar o custo de esterilização e proporcionar uma certa liberdade para a política monetária. 
Figura 2: Brasil - taxa de juros Selic (\% a.a.)

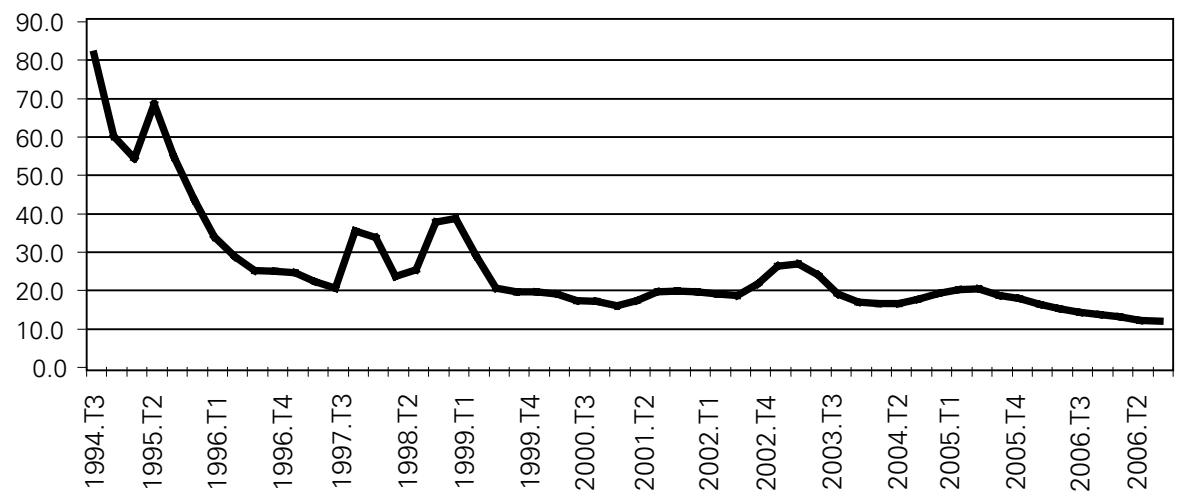

Fonte: IPEADATA

Após a crise de 1999 e a adoção do regime de câmbio flutuante, as autoridades econômicas implementaram uma série de normas que resultaram em aumento da liberalização financeira e maior flexibilidade do mercado cambial, incluindo a unificação dos mercados existentes (livre e flutuante); redução e posterior eliminação tanto da necessidade de maturidade mínima para empréstimos externos quanto do imposto sobre entrada de capitais; eliminação das restrições para investimentos no mercado de ações por parte de investidores estrangeiros, e simplificação dos procedimentos relacionados a remessa de capital para outros países ${ }^{5}$. Em 2005, o governo brasileiro concedeu ampla liberdade para compra e venda de moeda estrangeira no mercado de câmbio sem necessidade de autorização específica do BCB, observado o princípio de legalidade, e, em 2006, concedeu maior flexibilidade nas operações de cobertura cambial para exportação ao permitir que até $30 \%$ das receitas com exportações pudessem ser mantidas no exterior, sendo posteriormente estendido a $100 \%$.

Como vimos, durante o período do regime de câmbio semifixo, o BCB definia a taxa de câmbio dentro de uma minibanda; no entanto, após a desvalorização da moeda em 1999, o BCB passou a não ter mais compromisso em determinar a taxa de câmbio, operando ocasionalmente no mercado cambial em períodos de grande

\footnotetext{
${ }^{5}$ Em março de 2005 o BCB autorizou indivíduos e empresas a realizarem transferências de recursos para o exterior pelas suas próprias contas-correntes, uma simplificação as regras que acabou levando ao fim de conta CC-5. Sobre as normas cambiais nos anos 1990 e 2000 no Brasil, ver Paula (2011, cap. 4).

${ }^{6}$ Existem controvérsias relacionadas aos efeitos da liberalização financeira no Brasil. Goldfajn e Minella (2005) sustentam que, para usufruir os benefícios da abertura da conta capital, tal liberalização deveria ser acompanhada por reformas e fortalecimento de instituições - tal como a independência de jure do BCB. No entanto, as evidências empíricas de alguns estudos (Van der Laan, 2007; Paula, 2011) sugerem que a liberalização financeira no Brasil resultou em alta volatilidade da taxa de câmbio e baixo crescimento do PIB.
} 
volatilidade do fluxo de capital e, mais recentemente, de acordo com uma política de acúmulo de reservas internacionais. Assim, o regime cambial brasileiro não é um regime de livre flutuação, uma vez que o BCB intervém no mercado cambial, mas de fato tem sido um dos regimes cambiais, entre os países emergentes, que mais se aproxima de ser totalmente flutuante (Souza e Hoff, 2006). A partir do fim de 2002 a taxa de câmbio nominal (e também a real) apresentou uma forte tendência à sobrevalorização devido aos fluxos de divisas que resultaram do aumento dos superávits comerciais e da entrada de capitais externos (Figura 1). A valorização cambial, por sua vez, contribuiu fortemente para a redução na taxa de inflação que ocorreu a partir de 2004 (Tabela 1). O fluxo de capitais externos tem sido atraído pelo diferencial de rentabilidade entre os títulos nacionais e internacionais e melhoria no risco-país. Como pode ser visto na Figura 3, até 1997 grande parte do fluxo de capitais estava concentrada em investimentos de portfólio, enquanto que o declínio do fluxo de capitais foi liderado por investimentos em portfólio e outros investimentos ${ }^{7}$. Desde 1998, o IDE vem prevalecendo como principal fonte de entrada de capital. A forte elevação nos fluxos de capitais em 2006-2007 ocorreu em função do crescimento em todas as modalidades de capitais, capitais de portfólio, outros investimentos e IDE.

A vulnerabilidade externa foi bastante presente no Brasil desde metade da década de 1990. De fato, a razão dívida externa sobre exportações, um tradicional indicador de solvência externa, chegou a superar 4 em 1998-2000. Devido ao déficit em conta-corrente, que atingiu mais de 4\% do PIB em 1998, a economia brasileira ficou muito dependente do capital estrangeiro no fim da década de 1990, o que a deixou extremamente vulnerável a contágios externos. Mesmo após a adoção do regime de câmbio flutuante, em 1999, a economia brasileira sofreu forte pressão especulativa em 2001 e 2002, onde eventualmente houve uma "parada súbita" no fluxo de capitais, como fruto da desconfiança dos investidores em relação à eleição do presidente Lula. O crescimento das exportações desde 2002 — em função do boom de commodities — e a rápida redução da dívida externa (em particular da dívida pública ${ }^{8}$ ) resultou numa melhora dos indicadores de vulnerabilidade externa: a razão dívida externa sobre exportações reduziu-se de 3,8 em 2002 para 1,5 em 2007. Concomitantemente, as reservas cambiais aumentaram significativamente graças à política de acúmulo de reservas implementada pelo BCB, alcançando quase R \$ 170 bilhões em 2007 (Tabela 1). No entanto, as operações de esterilização têm sido custosas para o governo brasileiro, dada a grande diferença de taxa de juros entre títulos nacionais e internacionais. A razão dívida pública sobre PIB, que chegou a alcançar o patamar de mais de 50\% em 2002-2003, teve uma gradual redução a partir de 2004, favorecido pelo maior crescimento do produto e pela política de geração de superávits primários fiscais.

\footnotetext{
${ }^{7}$ Outros investimentos incluem créditos comerciais de curto e longo prazo, empréstimos, moeda e depósitos.

${ }^{8}$ Segundo dados da CEPAL, a razão dívida externa do governo federal sobre PIB no Brasil caiu de 17,4\% em 2002 para $4 \%$ em 2007.
} 
Figura 3: Brasil - fluxos de capitais em 1990-2007 (obrigações em US\$ bilhões)

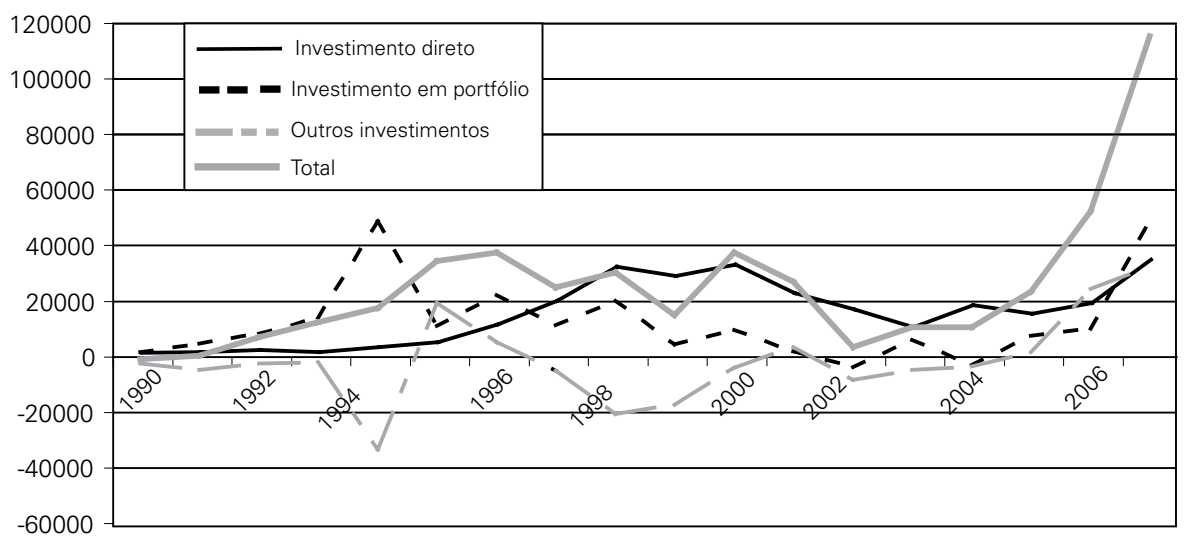

Fonte: IMF

\section{Rússia}

A Rússia, de 1990 a 2007, apresentou um crescimento médio baixo de apenas $2 \%$ a.a. Entretanto, dividindo-se a trajetória do crescimento econômico do país em dois períodos, antes e depois da crise financeira de 1998, tem-se dois cenários distintos: enquanto de 1990 até 1998 o crescimento real do PIB médio foi de 6\% negativos a.a., a média do crescimento em 1999-2007 foi elevada - cerca de 7\%. De fato, a economia russa experimentou, após 1990, um rápido e malsucedido processo de transição para uma economia de mercado, que incluiu privatizações de empresas estatais sem regras claras, brusca liberalização de preços, e um acelerado processo de liberalização financeira e comercial. O colapso do antigo sistema e a lenta adaptação ao sistema de mercado impôs pesados custos sociais em termos de desemprego, padrão de vida e distribuição de renda ${ }^{9}$. A prioridade da política econômica era diminuir os elevados níveis de inflação e, assim, o governo decidiu estabelecer a taxa de câmbio como âncora nominal da política monetária, com desvalorizações inferiores ao nível de inflação, o que resultou na apreciação da taxa de câmbio real (Figura 4). Em 1994 o governo russo iniciou uma gradual liberalização das restrições para investimentos em portfólio por parte de não residentes, que só foi plenamente concluída em 1998. O fraco desempenho da balança comercial combinado com uma política monetária apertada, sob o contexto de uma desordenada transição ao capitalismo, contribuiu para o baixo desempenho da economia no período 1990-1998.

\footnotetext{
${ }^{9}$ A taxa de desemprego cresceu rapidamente para mais de 10\% em 1997.
} 


\begin{tabular}{|c|c|c|c|c|c|c|c|c|c|c|c|c|c|}
\hline 오․ & $\bar{\infty}^{-}$ & $\overline{\bar{N}}$ & O & $\mid \begin{array}{l}0 \\
5 \\
5\end{array}$ & \begin{tabular}{l|}
0 \\
$\infty^{\circ}$
\end{tabular} & $\hat{N}$ & $\begin{array}{l}\stackrel{0}{\circ} \\
\stackrel{\sim}{N}\end{array}$ & $\begin{array}{l}\circ \\
\stackrel{0}{0} \\
\stackrel{6}{8} \\
q\end{array}$ & $\begin{array}{l}\sigma \\
\sigma^{\circ}\end{array}$ & $\begin{array}{l}\text { o } \\
\infty^{\circ} \\
\overbrace{}^{2}\end{array}$ & $\begin{array}{l}\text { s. } \\
\text { L }\end{array}$ & 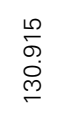 & $\underset{N}{N}$ \\
\hline ๕̊ํ․ & $\stackrel{⿱}{N}$ & $\begin{array}{l}\stackrel{\llcorner}{L^{\circ}} \\
\stackrel{\infty}{\leftarrow}\end{array}$ & $\hat{\sigma}$ & 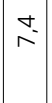 & $\circ$ & $\overline{8}$ & $\stackrel{\sim}{\sim}$ & $\begin{array}{l}\infty \\
\stackrel{0}{0} \\
\stackrel{D}{D} \\
\stackrel{N}{N}\end{array}$ & $\begin{array}{l}L \\
\sigma \\
\sigma\end{array}$ & $\begin{array}{l}\stackrel{\leftrightarrow}{\rho} \\
\stackrel{\rho}{\curvearrowright}\end{array}$ & $\frac{m}{m}$ & $\begin{array}{l}\text { o } \\
\stackrel{2}{ } \\
\text { ले } \\
\end{array}$ & $\begin{array}{l}0 \\
\infty \\
0 \\
\dot{\sigma}\end{array}$ \\
\hline 윰 & $\stackrel{\nabla}{\sigma}$ & $\stackrel{\AA}{\stackrel{1}{\circ}}$ & $\stackrel{\mathfrak{N}}{\stackrel{N}{*}}$ & $\stackrel{\circ}{\sim}$ & $\begin{array}{l}\stackrel{N}{0} \\
\mathscr{0}\end{array}$ & 店 & $\stackrel{m}{\infty} \underset{\sim}{\infty}$ & $\begin{array}{l}\bar{\sigma} \\
\infty \\
\stackrel{D}{\rho} \\
\sim\end{array}$ & $\stackrel{0}{=}$ & \begin{tabular}{c}
$\sim$ \\
ơ \\
\multirow{1}{*}{}
\end{tabular} & $\hat{m}$ & $\begin{array}{l}\underset{0}{0} \\
\text { m. } \\
\infty \\
\rightleftharpoons\end{array}$ & 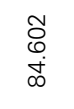 \\
\hline ఫ্ণ & $\stackrel{N}{\sim}$ & $\stackrel{+}{\underset{\leftarrow}{\infty}}$ & $\begin{array}{l}0 \\
0 \\
0\end{array}$ & \begin{tabular}{l|}
$\infty$ \\
$\forall$ \\
$\forall$
\end{tabular} & $\stackrel{\sim}{\sim}$ & $\begin{array}{l}\circ \\
\infty^{\circ}\end{array}$ & $\begin{array}{l}\infty \\
\stackrel{\infty}{\sim} \\
\stackrel{\infty}{N}\end{array}$ & 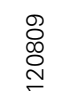 & $\overline{0}$ & $\underset{\check{I}}{\check{I}}$ & $\begin{array}{l}+ \\
0 \\
0 \\
ల\end{array}$ & $\begin{array}{l}\stackrel{L}{D} \\
\infty \\
\stackrel{\infty}{\infty} \\
\infty\end{array}$ & 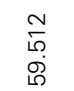 \\
\hline ஜ్రి & $\stackrel{m}{\sim}$ & \begin{tabular}{l}
$\stackrel{+}{\infty}$ \\
\hdashline
\end{tabular} & $\begin{array}{l}\hat{\mathrm{m}} \\
\stackrel{2}{2}\end{array}$ & it & $\frac{\Omega}{m}$ & $\begin{array}{l}L^{\circ} \\
\stackrel{\infty}{N}\end{array}$ & $\hat{\text { ̀े }}$ & $\frac{\stackrel{2}{\rho}}{\stackrel{m}{\wedge}}$ & $\begin{array}{c}N \\
\infty\end{array}$ & $\begin{array}{l}\stackrel{1}{0} \\
\ddot{\circ}\end{array}$ & 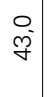 & 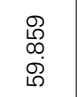 & $\begin{array}{l}\stackrel{0}{+} \\
\dot{ \pm} \\
\stackrel{\rho}{m}\end{array}$ \\
\hline ণั & $\stackrel{\sim}{\circ}$ & 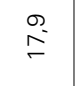 & $\begin{array}{l}\infty \\
\stackrel{\infty}{\rho}\end{array}$ & $\cong$ & \begin{tabular}{|l|} 
\\
0 \\
0 \\
$ల$
\end{tabular} & $\begin{array}{l}\circ \\
\stackrel{\circ}{N}\end{array}$ & $\stackrel{+}{\dot{m}}$ & $\begin{array}{l}\text { 苟 } \\
\text { Oे }\end{array}$ & $\begin{array}{l}+ \\
\infty\end{array}$ & $\stackrel{m}{i}$ & $\underset{f}{\check{f}}$ & 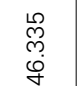 & $\begin{array}{l}\stackrel{8}{ } \\
\stackrel{1}{*} \\
\stackrel{N}{N}\end{array}$ \\
\hline ¿্ণ & $\bar{\sigma}$ & $\begin{array}{l}\sigma^{\infty} \\
\infty^{-}\end{array}$ & $\stackrel{\llcorner}{\bar{N}}$ & $\bar{m}$ & $\begin{array}{l}\mathscr{S} \\
\stackrel{y}{f}\end{array}$ & $\begin{array}{l}\stackrel{\Omega}{ } \\
\stackrel{+}{N}\end{array}$ & $\stackrel{\text { N }}{\text { సे }}$ & $\begin{array}{l}\underset{\mathcal{N}}{\sim} \\
\underset{m}{N}\end{array}$ & $\subsetneq$ & $\begin{array}{l}0 \\
8 \\
8\end{array}$ & $\begin{array}{c}\mathrm{N} \\
\stackrel{9}{g} \\
\end{array}$ & 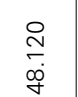 & 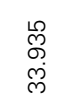 \\
\hline ঃ্ণ & $\begin{array}{l}\circ \\
\stackrel{0}{\circ}\end{array}$ & $\begin{array}{l}\stackrel{s}{0} \\
\oplus\end{array}$ & $\begin{array}{l}\infty \\
0 \\
0\end{array}$ & $\stackrel{i}{i}$ & $\begin{array}{l}1 \\
0^{\circ} \\
\omega^{\circ}\end{array}$ & $\stackrel{+}{\infty}$ & $\stackrel{\bar{\infty}}{\sim}$ & 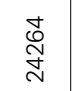 & $\begin{array}{l}0 \\
\infty^{\circ}\end{array}$ & 实 & $\begin{array}{l}0 \\
8 \\
8\end{array}$ & $\begin{array}{l}\overline{1} \\
\stackrel{8}{8}\end{array}$ & $\begin{array}{l}\text { Pे } \\
\infty \\
\dot{q}\end{array}$ \\
\hline ஓ & $\stackrel{ナ}{\sigma}$ & $\stackrel{+}{\underset{\leftarrow}{\leftarrow}}$ & $\begin{array}{l}\hat{L} \\
\infty \\
\infty\end{array}$ & $\stackrel{\sim}{\sim}$ & $\begin{array}{l}\infty \\
\infty \\
\infty \\
\infty\end{array}$ & $\stackrel{\infty}{\stackrel{\infty}{\Sigma}}$ & $\begin{array}{l}0 \\
\stackrel{\mathbb{N}}{ }\end{array}$ & 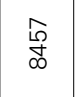 & $\begin{array}{l}0 \\
\stackrel{I}{I}\end{array}$ & $\stackrel{+}{\grave{N}}$ & ने & $\begin{array}{l}+ \\
\delta \\
\dot{0} \\
\dot{m}\end{array}$ & $\begin{array}{l}0 \\
\dot{0} \\
\dot{\sim}\end{array}$ \\
\hline$\stackrel{\infty}{\stackrel{一}{\circ}}$ & m) & $\stackrel{\sim}{\mathscr{\sigma}}$ & 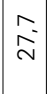 & $\begin{array}{l}\infty \\
f \\
f\end{array}$ & 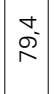 & $\stackrel{\infty}{\stackrel{\infty}{\sim}}$ & $\hat{\sigma}$ & 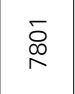 & $\overline{0}$ & $\stackrel{\vec{\sim}}{\sim}$ & s. & $\begin{array}{l}\stackrel{乛}{\checkmark} \\
\underset{\sim}{0} \\
\stackrel{\sigma}{6}\end{array}$ & $\stackrel{\sigma}{\sim}$ \\
\hline ஓ̆ & $\stackrel{\forall}{\leftrightarrows}$ & $\begin{array}{l}m \\
\infty^{\circ} \\
\sim\end{array}$ & $\begin{array}{l}\infty \\
\underset{\tau}{-}\end{array}$ & 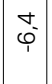 & 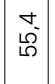 & $\stackrel{\sim}{\sigma}$ & $\stackrel{\infty}{\infty}$ & $\begin{array}{l}\stackrel{L}{\circ} \\
\stackrel{\infty}{\mathrm{N}} \\
\stackrel{\leftarrow}{\leftarrow}\end{array}$ & 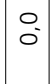 & $\stackrel{9}{\stackrel{9}{F}}$ & $\mid \begin{array}{c}0 \\
\stackrel{y}{y}\end{array}$ & $\begin{array}{l}\stackrel{m}{\sigma} \\
\stackrel{+}{+}\end{array}$ & 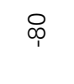 \\
\hline$\stackrel{\circ}{\mathscr{\swarrow}}$ & $\stackrel{\varphi}{\ddot{P}}$ & $\begin{array}{l}\stackrel{0}{\circ} \\
\text { ¿ }\end{array}$ & $\hat{f}$ & $\stackrel{⿱}{i}$ & $\bar{m}$ & $\begin{array}{l}0 \\
\stackrel{N}{N}\end{array}$ & $\bar{\sigma}$ & 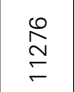 & $\begin{array}{l}\infty \\
\stackrel{\infty}{N}\end{array}$ & $\begin{array}{l}0 \\
\oplus \\
\bullet\end{array}$ & 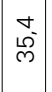 & $\begin{array}{l}\bar{\sigma} \\
\stackrel{\bar{\sim}}{N}\end{array}$ & $\begin{array}{l}\text { f } \\
\infty \\
\stackrel{0}{\circ}\end{array}$ \\
\hline 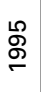 & 广্ণ & $\bar{i}$ & $\begin{array}{l}\stackrel{L}{0} \\
\stackrel{2}{\sigma}\end{array}$ & $\begin{array}{l}\stackrel{9}{f} \\
f \\
f\end{array}$ & $\begin{array}{l}\check{\sigma} \\
\dot{\sigma}\end{array}$ & $\stackrel{0}{\stackrel{0}{5}}$ & $\stackrel{0}{\underset{\forall}{*}}$ & $\begin{array}{l}\mathscr{m} \\
\stackrel{\infty}{\sim} \\
\stackrel{\sim}{\leftarrow}\end{array}$ & $\stackrel{N}{N}$ & 임 & $\begin{array}{c}m \\
\stackrel{m}{g} \\
\tilde{g}\end{array}$ & $\begin{array}{l}\stackrel{0}{0} \\
\infty \\
\stackrel{\sigma}{\sigma}\end{array}$ & $\begin{array}{l}\llcorner 0 \\
\mathscr{O} \\
\emptyset \\
\oplus\end{array}$ \\
\hline ஓ̆ & $\hat{\stackrel{N}{T}}$ & $\stackrel{\infty}{\bar{\sim}}$ & $\begin{array}{l}0 \\
\hat{0} \\
0\end{array}$ & $\underset{\dot{\Sigma}}{\dot{\Sigma}}$ & $\begin{array}{c}\mathcal{N} \\
0 \\
\sigma\end{array}$ & $\begin{array}{l}\text { o̊ } \\
\stackrel{5}{\sigma}\end{array}$ & $\underset{\sim}{\sim}$ & 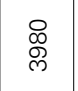 & $\begin{array}{l}\infty \\
\sim\end{array}$ & $\stackrel{g}{\sim}$ & $\mid \begin{array}{c}\dot{D} \\
\dot{\Sigma}\end{array}$ & 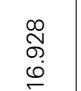 & 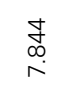 \\
\hline ஜֶু & $\widehat{\widehat{o}}$ & 穴 & $\begin{array}{l}0 \\
\mathbb{T} \\
\infty\end{array}$ & $\begin{array}{r}\dot{\dot{E}} \\
\dot{\Sigma}\end{array}$ & $\begin{array}{l}\widehat{1} \\
0^{\circ}\end{array}$ & $\underset{\check{I}}{\check{1}}$ & $\stackrel{\circ}{-}$ & $\begin{array}{l}\stackrel{L}{\infty} \\
\infty \\
\stackrel{\infty}{\infty}\end{array}$ & $\stackrel{t}{\stackrel{\sigma}{-}}$ & ه্் & $\mid \underset{\dot{x}}{\dot{\Sigma}}$ & $\underset{\check{C}}{\dot{x}}$ & $\begin{array}{l}8 \\
\stackrel{0}{0} \\
\text { i }\end{array}$ \\
\hline & 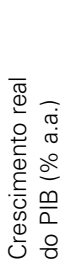 & 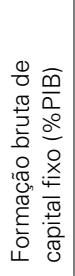 & 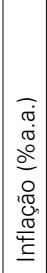 & 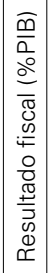 & 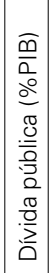 & 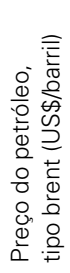 & 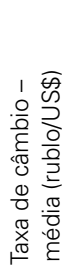 & 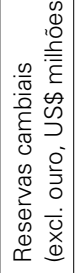 & 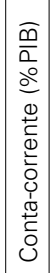 & 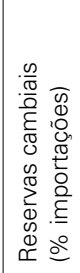 & 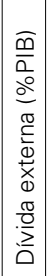 & 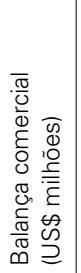 & 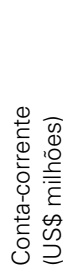 \\
\hline
\end{tabular}


Segundo Owen e Robinson (2003, pp. 25-26), as origens da crise russa de 1998 estão relacionadas a alguns desequilíbrios econômicos: um grande déficit orçamentário (7,4\% do PIB em 1996 e 6,4\% em 1997), com grande endividamento de curto prazo; falta de reformas estruturais no setor bancário, nos monopólios naturais e no setor agrícola; efeitos da crise asiática, que contribuiu para uma queda no preço das commodities e iniciou uma acentuada deterioração dos termos de troca russo - resultando em um súbito declínio no superávit comercial de US\$ 21,6 bilhões em 1996 para US\$ 14,9 bilhões em 1997 (Tabela 2). O contágio da crise asiática resultou em um substancial aumento no custo de captação e reduziu o volume de capital estrangeiro. As autoridades russas conseguiram um acordo financeiro com o FMI, Banco Mundial e Japão, e anunciaram medidas de emergência em agosto de 1998, incluindo o default da dívida atrelada ao rublo com prazo de vencimento anterior a 1999; um ajuste na banda cambial; e a reintensificação dos controles de capitais, como tentativa de amenizar as pressões sobre a reservas internacionais. A reação negativa do mercado, que refletia a ainda frágil situação fiscal, forçou rapidamente a cotação do rublo ao limite da nova banda, o que levou ao abandono do regime cambial em 2/9/1998, que passou a ser flutuante.

Figura 4: Rússia - taxa de câmbio real efetiva (média do período, base $2000=100$ )

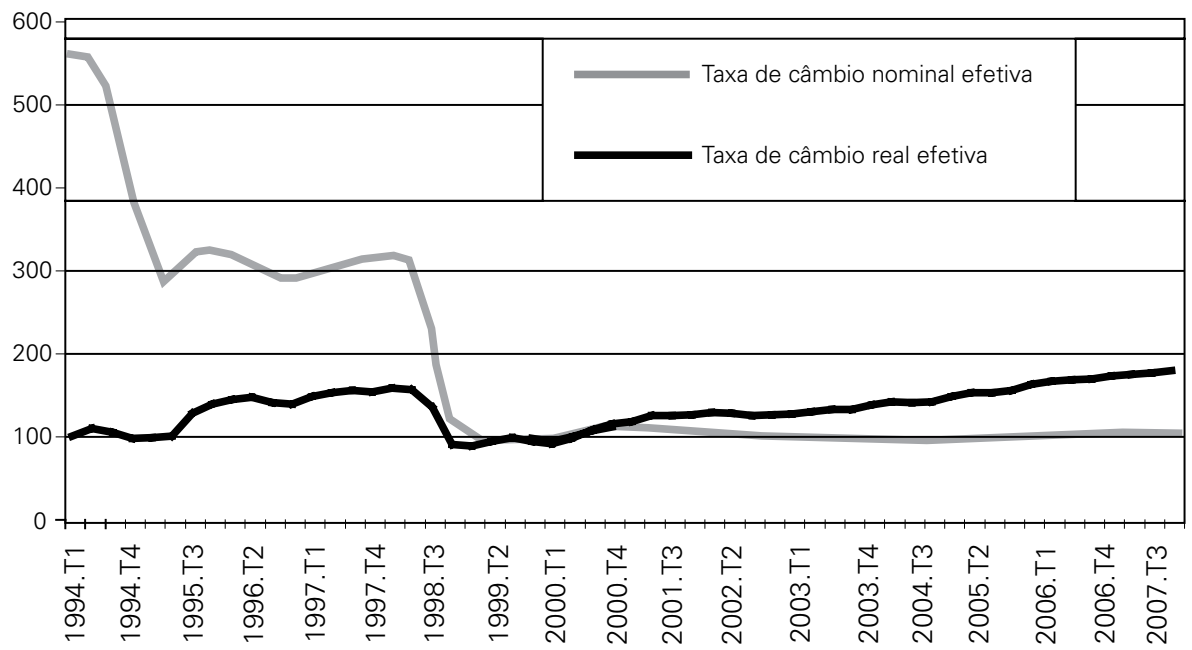

Fonte: IMF e Banco Central da Rússia

O colapso econômico que se seguiu à crise russa de 1998 não foi tão profundo como em outros países que passaram por crises semelhantes, e a recuperação foi rápida, devido a uma série de fatores: (i) uma substituição de importações estimulada por uma forte desvalorização da taxa de câmbio; (ii) o fato de que os canais de transmissão pelos quais os choques externos são normalmente transmitidos ao setor real foram menos relevantes, uma vez que a riqueza do setor industrial esta- 
va fora do setor bancário, e (iii) os termos de troca positivos gerados pela subida do preço internacional do petróleo (Owen e Robinson, 2003, pp. 7-9). Além disso, o Banco Central da Rússia (BCR) agiu rapidamente para resolver os problemas do setor bancário, colaborando na situação de liquidez dos bancos, o que evitou uma corrida para retirada de depósitos.

O desempenho da economia russa pós-crise foi fortemente contrastante com o desempenho do período anterior. No ano 2000, os altos preços do petróleo - a média do preço do barril aumentou de US\$12,8 em 1998 para US\$28,4 em 2000 - contribuiu para uma rápida melhoria no desempenho comercial e consequentemente na taxa de crescimento da economia. O aumento na demanda agregada estimulou o crescimento econômico, favorecido pela elevação de salários e pensões, pelo aumento das exportações e pelo declínio das taxas de juros, em função da adoção de uma política monetária mais expansionista, estimulando também a expansão do crédito bancário, que cresceu de $12 \%$ do PIB em 1999 para $22 \%$ em 2003. O desempenho do setor energético (petróleo, gás e derivados) impactou diretamente e indiretamente no crescimento do produto, já que esse setor sozinho responde por $20 \%$ do PIB e alavanca outros setores industriais (como construção e maquinaria). A recuperação econômica pós-crise de 1998 foi sustentada, uma vez que a desvalorização da taxa de câmbio real forneceu um forte incentivo à competitividade do setor "tradeables", que se traduziu em crescimento na produção de diversos setores da economia. Até 2004, o setor de petróleo e alguns setores industriais foram a alavanca do crescimento, sendo que a expansão subsequente foi determinada fortemente pelo crescimento de bens não comercializáveis e de serviços, incluindo bens manufaturados, construção e comércio varejista (World Bank, 2008).

Figura 5: Rússia - fluxos de capitais (obrigações em US\$ milhões)

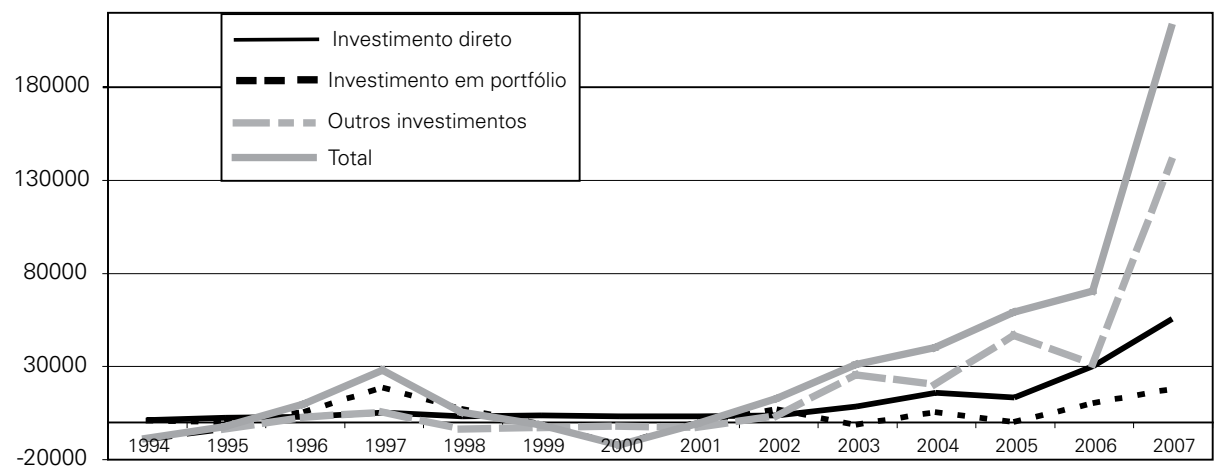


Favorecido pelo aumento do preço do petróleo, o superávit comercial aumentou de US\$ 16,4 bilhões em 1998 para US\$ 36 bilhões em 1999, e atingindo o saldo de US\$ 139,3 bilhões em $2006^{10}$. Como resultado, a relação saldo da Conta-Corrente e PIB aumentou de 0,1\% em 1998 para 11,1\% em 2005, vindo a reduzir a partir de 2006-2007 em função do aumento no déficit em rendas de investimento. As reservas cambiais até 1999 eram relativamente baixas, cobrindo apenas $20 \%$ das importações russas, mas desde 2004 tal razão tem estado acima de $120 \%$. O contínuo e acentuado aumento nas reservas de US\$ 8,5 bilhões em 1999 para cerca de US\$ 209 bilhões em 2007 se deu graças a uma política de acúmulo de reservas, favorecido pelo contexto de elevado superávit na conta-corrente e forte entrada de capitais externos. De modo geral, todos indicadores de vulnerabilidade externa tiveram uma clara melhora desde 1999. Particularmente, a razão dívida externa sobre PIB caiu de 91,7\% em 1998 para 31,3\% em 2006. Após muitos anos de substancial saída de capitais, o fluxo se inverteu em 2002, com significativa redução na saída de capitais e forte elevação na entrada, puxado principalmente pelos fluxos de "outros investimentos" e, em menor grau, pelo IDE (Figura 5). Em que pese a melhoria nos indicadores de vulnerabilidade externa devido aos superávits em contas-correntes e a forte elevação nas reservas cambiais, a grande dependência da Rússia às exportações de recursos energéticos contribuiu para tornar a economia russa vulnerável a mudanças nos preços do petróleo ${ }^{11}$.

A Rússia adotou, após 1998, um regime cambial de flutuação administrada, com conversibilidade parcial na conta de capital. O BCR persegue diversos objetivos, e evita um aperto forte na política monetária, temendo uma diminuição no ritmo do crescimento da economia. A principal meta do BCR tem sido acumular reservas internacionais e evitar bruscas apreciações da taxa de câmbio real, mantendo relativamente estável a taxa de câmbio efetiva nominal, em um esforço para preservar a competitividade do setor manufatureiro e também amenizar o ajustamento na taxa de câmbio, enquanto que o controle da inflação tem sido uma importante, porém secundária, preocupação ${ }^{12}$. A inflação, mesmo mantendo-se alta, diminuiu a cada ano, apesar do relaxamento monetário e de pressões inflacionárias mais recentes causadas pelo aumento nos preços de alimentos importados (Figura 6 e Tabela 2). Apesar da ação do BCR no mercado de câmbio de procurar arrefecer a tendência à valorização cambial ante o forte aumento na oferta de dividas resultante da combinação entre superávits em conta-corrente e aumento no afluxo de capitais, a taxa de câmbio real efetiva vem se apreciando desde 2003, retornando aos patamares pré-crise de 1998, em consequência sobretudo da inflação domésti-

\footnotetext{
${ }^{10}$ Em 2007, o saldo comercial declinou para US\$ 131 bilhões, devido ao crescimento maior das importações em relação às exportações.

${ }^{11}$ A participação dos recursos energéticos nas exportações da Rússia aumentou gradualmente de 51,2\% em 2001 para 63,3\% em 2006 (World Bank, 2007, p. 29).

${ }^{12}$ Diversos estudos econométricos mostram que a política monetária, desde 1990, tende a ter uma meta implícita para a taxa de câmbio. Ver, entre outros, Esanov et al. (2005).
} 
ca ainda elevada (mais de $9 \%$ a.a.) em um contexto em que a taxa de câmbio nominal efetiva tem se mantido estável (Figura 4) ${ }^{13}$.

O governo russo faz uso de alguns tipos de controle de capitais tanto na saída quanto na entrada, apesar de que, recentemente, várias transações financeiras tenham sido liberalizadas. Os controles na saída de capital incluem a necessidade permissão do BCR para realizar investimentos em portfólio no estrangeiro e o requisito de que as instituições russas de crédito devam possuir reservas para operações com não residentes (Mohanty e Scatigna, 2005, p. 52). Em 2004, o BCR implementou requerimentos de reserva sobre entrada de capitais, com uso moderado e justificado pela necessidade de proteger o ainda frágil setor bancário de uma maior volatilidade no fluxo de capitais. Outras restrições à entrada de capitais incluem a necessidade de permissão do BCR para obtenção de fundos no exterior.

Figura 6: Rússia - taxa de juros (\% a.a.)

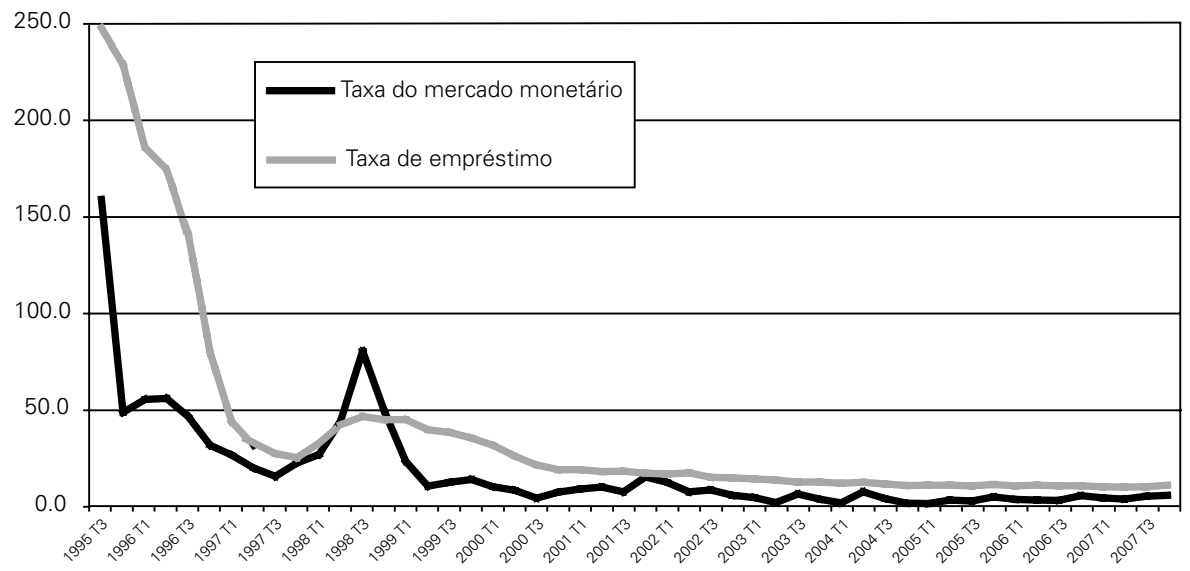

Fonte: Banco Central da Rússia

A compra de divisas em larga escala feita pelo BCR - através de intervenções não esterilizadas - tem sido combinada com grandes superávits fiscais, favorecidos pelas receitas advindas das exportações de produtos energéticos. Como visto, o BCR tem resistido à apreciação nominal do rublo com fortes intervenções monetárias, aumentando assim a liquidez do sistema financeiro. A esterilização dos fluxos de capitais tem sido dificultada em função do tamanho pequeno do mercado de títulos na Rússia, o que acaba resultando em uma pressão baixista sobre a taxa de juros doméstica (World Bank, 2008; ver também Figura 6). Desde 1999 a condição fiscal do país se fortaleceu em decorrência do ajuste nas contas públicas equivalente a 9,5\% do PIB de 1997 a 2001, como resultado tanto das receitas

\footnotetext{
${ }^{13}$ A persistência de uma taxa de câmbio real se apreciando gradualmente tem afetado a competitividade das exportações de setores comercializáveis que não sejam recursos naturais e metais.
} 
provenientes do petróleo como de uma redução dos gastos governamentais. Em 2004-2006 houve um aumento considerável do superávit fiscal (de 2,4\% em 2003 para $7,5 \%$ do PIB em 2006), devido à renda extra proveniente da elevação dos preços do petróleo.

O Fundo de Estabilização do Petróleo, criado em 2004, onde grande parte das rendas fiscais extras provenientes do petróleo é acumulada, tem um papel crucial na manutenção dos superávits ${ }^{14}$. Em 2005, cerca de dois terços do aumento das rendas provenientes da exportação petróleo, gás e derivados foram efetivamente esterilizados pelo Fundo de Estabilização (OECD, 2006). Uma flexibilidade fiscal foi introduzida em 2006 com a criação do Fundo de Investimentos no orçamento federal. O objetivo desse fundo é financiar investimentos em infra estrutura e inovação, sob a forma de parcerias público-privadas (PPPs).

\section{Índia}

A Índia, após anos de baixo crescimento econômico e após a crise financeira de 1991, teve uma drástica mudança na sua trajetória de sua economia: o crescimento real do PIB foi, em média, de 6,4\% no período 1990-2007, enquanto no período 1971-1980 foi de 3,1\% e em 1981-1990 4,7\% (Ariff e Khalid, 2005, p. 97). Apesar do país ainda apresentar uma enorme carência em infra estrutura, as taxas de investimento aumentaram de cerca de $22 \%$ na primeira metade dos anos 1990 para $28 \%$ a partir de 2004 . Esse desempenho econômico foi resultado, entre outros fatores, do enorme potencial do seu mercado consumidor, da existência de um segmento de trabalhadores bem qualificados, do amplo crescimento da produtividade do país, da eficiente coordenação da política econômica, e da implementação gradual de reformas econômicas. A liberalização da conta capital foi parte de um amplo programa de reformas econômicas que incluíram o fim da licença industrial, uma significativa redução dos impostos de importação, e liberalização das transações relacionadas à conta-corrente.

O processo de liberalização econômica se acelerou após a crise da dívida externa em 1991, quando a moeda local (rúpia) foi desvalorizada em dois momentos, totalizando $20 \%$ de perda de valor em relação ao dólar (Figura 11). A liberalização teve início com um intenso processo de liberalização comercial; como resultado, as tarifas de importação foram reduzidas de uma média de $87 \%$ em 1991 para 25\% em 1997 (IMF, 2001, p. 32). Sob um ambiente de reforma econômica, a conta capital foi gradualmente flexibilizada e o regime cambial deixou de ser fixo, passando a um regime de câmbio flutuante administrado. Essa mudança teve início com a transição de um modelo de flutuação adminis-

\footnotetext{
${ }^{14}$ As quantias envolvidas no Fundo de Estabilização foram inicialmente pequenas mas crescentes ao longo do tempo: de US\$ 18 bilhões em 2004 para US\$ 89 bilhões em 2006 e US\$ 141 bilhões em setembro de 2007 (World Bank, 2007, p. 29).
} 
trada indexado a uma cesta de moedas para um regime de câmbio dual, em março de 1992. Em março de 1993, a Índia adotou um sistema de câmbio unificado e flutuante, acompanhado por uma flexibilização das transações em conta-corrente, que culminou na conversibilidade plena em agosto de 1994, acatando formalmente as obrigações do Artigo VII do FMI. Apesar de a Índia ter adotado formalmente um regime de câmbio flutuante, na prática essas flutuações são parcialmente administradas, uma vez que o Banco de Reserva da Índia (Reserve Bank of India - RBI) exerce um papel crucial no mercado cambial. De fato, o RBI tem sido uma atuação importante no mercado de divisas, uma vez que atua para evitar que grandes transações nesse mercado aumentem a volatilidade da taxa de câmbio e, ao mesmo tempo, procura interferir de algum modo na trajetória de longo prazo da taxa de câmbio real efetiva.

\section{Tabela 3: Índia - principais indicadores econômicos}

\begin{tabular}{|c|c|c|c|c|c|c|c|c|c|}
\hline & 1990 & 1991 & 1992 & 1993 & 1994 & 1995 & 1996 & 1997 & 1998 \\
\hline $\begin{array}{l}\text { Crescimento real } \\
\text { do PIB (\% a.a.) }\end{array}$ & 5,3 & 1,4 & 5,4 & 5,7 & 6,4 & 7,3 & 8,0 & 4,3 & 6,7 \\
\hline $\begin{array}{l}\text { Formação bruta de } \\
\text { capital fixo (\%PIB) }\end{array}$ & 22,9 & 22,0 & 22,4 & 21,5 & 21,9 & 24,4 & 23,1 & 23,0 & 22,8 \\
\hline Inflação (\%a.a.) & 9,0 & 13,9 & 11,8 & 6,4 & 10,2 & 10,2 & 9,0 & 7,2 & 13,2 \\
\hline Resultado fiscal* (\%PIB) & $-7,6$ & $-5,5$ & $-5,3$ & $-7,0$ & $-5,6$ & $-5,0$ & $-4,9$ & $-4,9$ & $-5,3$ \\
\hline Dívida pública* (\%PIB) & 60,5 & 64,7 & 63,5 & 64,3 & 61,5 & 58,6 & 55,7 & 57,5 & 57,5 \\
\hline $\begin{array}{l}\text { Taxa de câmbio - média } \\
\text { (rúpia/US\$) }\end{array}$ & 17,5 & 22,7 & 25,9 & 30,5 & 31,4 & 32,4 & 35,4 & 36,3 & 41,3 \\
\hline $\begin{array}{l}\text { Reservas cambiais } \\
\text { (excl. ouro, US\$ milhões) }\end{array}$ & 1.521 & 3.627 & 5.757 & 10.199 & 19.699 & 17.922 & 20.170 & 24.688 & 27.341 \\
\hline Conta-corrente (\%PIB) & $-2,5$ & $-1,6$ & $-1,2$ & $-0,6$ & $-0,5$ & $-1,6$ & $-1,7$ & $-0,7$ & $-1,7$ \\
\hline $\begin{array}{l}\text { Reservas cambiais } \\
\text { (\% importações) }\end{array}$ & 6,5 & 17,2 & 25,1 & 42,3 & 66,4 & 47,2 & 46,1 & 54,0 & 61,0 \\
\hline Dívida externa $(\% \mathrm{PIB})^{* *}$ & 26,7 & 32,4 & 37,3 & 34,7 & 32,1 & 26,8 & 24,3 & 23,2 & 23,7 \\
\hline $\begin{array}{l}\text { Dívida externa/ } \\
\text { exportações** }\end{array}$ & 4,7 & 4,7 & 4,8 & 4,2 & 3,8 & 2,0 & 2,7 & 2,6 & 2,8 \\
\hline $\begin{array}{l}\text { Dívida de longo prazo } \\
\text { (\% dívida externa)** }\end{array}$ & 86,6 & 87,7 & 87,6 & 90,8 & 91,6 & 92,1 & 91,4 & 93,9 & 95,3 \\
\hline $\begin{array}{l}\text { Balança comercial } \\
\text { (US\$ milhões) }\end{array}$ & -5.151 & -2.992 & -2.912 & -2.092 & -4.150 & -6.718 & -10.052 & -10.028 & -10.752 \\
\hline $\begin{array}{l}\text { Conta-corrente } \\
\text { (US\$ milhões) }\end{array}$ & -7.888 & -4.438 & -3.349 & -1.624 & -1.677 & -5.566 & -6.050 & -3.003 & \\
\hline $\begin{array}{l}\text { Crescimento real do PIB } \\
\text { (\% a.a.) }\end{array}$ & 6,4 & 4,4 & 5,8 & 3,8 & 8,5 & 7,5 & 9,4 & 9,6 & 8,7 \\
\hline $\begin{array}{l}\text { Formação bruta de } \\
\text { capital fixo (\%PIB) }\end{array}$ & 23,4 & 22,7 & 23,6 & 23,8 & 24,9 & 28,4 & 31,0 & 32,5 & 34,6 \\
\hline Inflação (\%a.a.) & 4,7 & 4,0 & 3,7 & 4,4 & 3,8 & 3,8 & 4,3 & 5,8 & 6,4 \\
\hline Resultado fiscal* (\%PIB) & $-5,4$ & $-5,2$ & $-4,7$ & $-6,3$ & $-6,0$ & $-5,1$ & $-4,2$ & $-3,7$ & $-3,3$ \\
\hline
\end{tabular}




\begin{tabular}{|c|c|c|c|c|c|c|c|c|c|}
\hline Dívida pública* (\%PIB) & 58,9 & 61,5 & 65,6 & 69,1 & 68,1 & 67,5 & 65,9 & 63,6 & 63,6 \\
\hline $\begin{array}{l}\text { Taxa de câmbio - média } \\
\text { (rúpia/US\$) }\end{array}$ & 43,1 & 44,9 & 47,2 & 48,6 & 46,6 & 45,3 & 44,1 & 45,3 & 41,4 \\
\hline $\begin{array}{l}\text { Reservas cambiais } \\
\text { (excl.ouro, US\$ milhões) }\end{array}$ & 32.667 & 37.902 & 45.871 & 67.666 & 98.938 & 126.593 & 131.924 & 170.738 & 266.988 \\
\hline Conta-corrente (\%PIB) & $-0,7$ & $-1,0$ & 0,3 & 1,4 & 1,5 & 0,1 & $-1,3$ & $-1,1$ & $-1,4$ \\
\hline $\begin{array}{l}\text { Reservas cambiais (\% im- } \\
\text { portações) }\end{array}$ & 71,7 & 70,3 & 89,6 & 123,7 & 145,3 & 132,5 & 97,9 & 102,4 & n.d. \\
\hline Dívida externa (\%PIB)** & 22,0 & 21,8 & 20,8 & 20,8 & 18,9 & 18,0 & 15,4 & 16,9 & n.d. \\
\hline $\begin{array}{l}\text { Dívida externa/ } \\
\text { exportações*** }\end{array}$ & 2,6 & 2,2 & 2,2 & 2,0 & 1,7 & 1,5 & 1,2 & 1,2 & n.d. \\
\hline $\begin{array}{l}\text { Dívida de longo prazo } \\
\text { (\% dívida externa)** }\end{array}$ & 96,0 & 96,5 & 97,2 & 96,1 & 95,5 & 94,0 & 92,9 & 92,2 & n.d. \\
\hline $\begin{array}{l}\text { Balança comercial } \\
\text { (US\$ milhões) }\end{array}$ & -8.679 & -10.640 & -6.419 & -3.561 & -7.188 & -17.600 & -32.526 & -43.078 & n.d. \\
\hline $\begin{array}{l}\text { Conta-corrente } \\
\text { (US\$ milhões) }\end{array}$ & -3.232 & -4.599 & 1.410 & 7.061 & 8.773 & 781 & -10.285 & -9.800 & n.d. \\
\hline
\end{tabular}

Fonte: IMF - International Financial Statistics, ADB - ADB Indicators (dívida externa e crescimento real do PIB) e Deutche Bank Research (dívida pública).

OBS.: $\left(^{*}\right)$ Somente governo central. $\left(^{* *}\right)$ Dados correspondentes ao ano fiscal na Índia (abril a março do ano seguinte).

Comparada a outros países que adotaram o regime de câmbio flutuante, a volatilidade da taxa de câmbio nominal na Índia tem sido baixa (IMF, 2001, p. 152). O câmbio, combinado a outras ferramentas extracambiais, tem sido usado para absorver choques externos. Em geral, a taxa de câmbio nominal apresentou uma tendência de gradual desvalorização em 1995-2002, se depreciando a partir de então, sendo tal movimento acompanhado grosso modo pela taxa de câmbio real efetiva. De fato, durante a década de 1990, o RBI seguiu uma regra de paridade do poder de compra (PPP), que indexava a taxa de câmbio nominal no nível de preços, visando afetar a taxa de câmbio real (Figura 7). Contudo, desde o início dos anos 2000 a política cambial começou a sofrer pequenas alterações no seu curso, passando a um regime mais flexível, mas ainda preocupado em amenizar uma maior volatilidade cambial (Kohli, 2005, p. 153). 
Figura 7: Índia - TCRE e TCNE (\% a.a. média, ponderação das exportações)

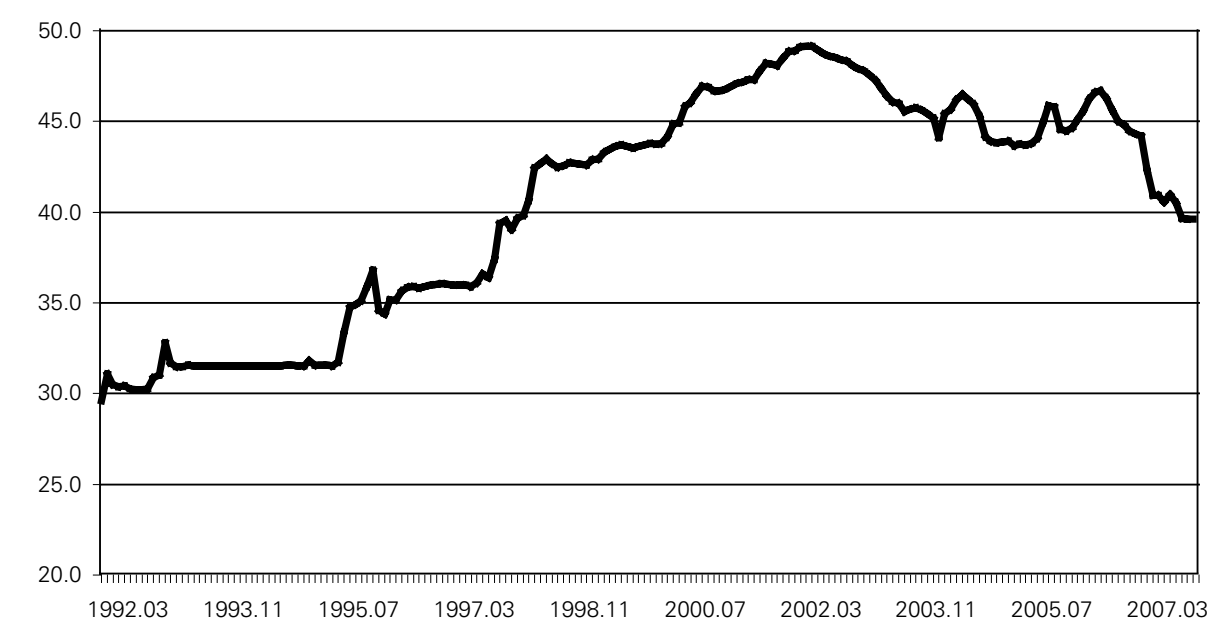

Fonte: RBI

A abordagem sobre a liberalização da conta capital tem sido cautelosa na Índia, moldada pelas lições aprendidas com a crise da dívida externa em 1991: o que é liberalizado está especificado, enquanto todo o resto continua restrito ou proibido. Assim, a liberalização gradual da conta capital tem privilegiado a abertura da economia para IDE e investimentos em portfólio, ao invés de endividamento externo, visando reduzir a vulnerabilidade do país a crises externas (Habermeier, 2000, p. 80). Quanto à entrada de capitais, a liberalização financeira começou com uma política mais flexível de IDE em julho de 1991, quando os investimentos com mais de $51 \%$ das ações recebiam aprovação automática para 35 setores industriais considerados de alta prioridade, sujeitos apenas a um processo de registro no RBI; ao longo do tempo, a aprovação automática tem sido progressivamente ampliada. Em seguida, em 1992, a liberalização foi estendida aos investimentos em portfólio, quando instituições estrangeiras de investimento foram autorizadas a investir no mercado secundário de ações, sujeito ao teto de $5 \%$. O passo seguinte foi a liberalização seletiva dos empréstimos comerciais externos, que eram aprovados pelo governo caso a caso, com o critério de aprovação dependendo do montante emprestado, do tempo de maturidade e do objetivo do empréstimo (Nayyar, 2002).

$\mathrm{Na}$ Índia há uma predominância dos controles quantitativos em relação àqueles baseados no mercado, administrativamente determinados e que distinguem claramente as transações de residentes e de não residentes - portanto, podendo ser caracterizados como controles abrangentes, em contraste com controles seletivos e temporários (Aryoshi et al., 2000). Por outro lado, predominam controles sobre a saída de capitais e uma considerável abertura na entrada de capitais. Particularmente, a saída de capitais de residentes tem sido mais limitada: enquanto individualmente há muitas restrições, para firmas domésticas a saída de capitais é possí- 
vel dentro de alguns limites estipulados pelo governo. Recentemente, essas restrições têm sido relaxadas para permitir maiores investimentos no exterior, tanto para indivíduos quanto para empresas nacionais ${ }^{15}$. Os controles de capitais na Índia também tem sido dinâmico, ou seja, o governo tende a apertar o controle sobre a saída de capitais nos momentos de maior especulação cambial para afrouxá-los em seguida (Epstein et al., 2003, p. 30).

Em função do forte aumento das reservas cambiais e aos limites à acumulação de dívida externa, grande parte dos indicadores de vulnerabilidade externa mostrou contínua melhora desde 1991: apesar da razão entre dívida externa e PIB ter aumentado gradualmente durante os anos 1990, o endividamento externo declinou de 37\% do PIB em 1992 para menos de 24\% em 1996, e vindo a atingir a menos de $20 \%$ do PIB a partir de 2003. Além disso, desde 1993 a participação da dívida de longo prazo no total da dívida externa tem sido maior que $90 \%$ - uma clara evidência de que a reorientação da política em relação à conta capital tem sido bem-sucedida. A razão dívida externa sobre exportações passou de mais de 4,0 em 1990-1993 para menos de 3,0 a partir de 1995 e menos de 2,0 a partir de 2003, chegando a alcançar a 1,2 em 2005-2006, um percentual considerado seguro pelo mercado financeiro internacional ${ }^{16}$. Finalmente, a razão reservas cambiais sobre importações aumentou para mais de $100 \%$ em 2002, o que é expressivo quando comparado aos $20 \% 40 \%$ do começo dos anos 1990. De fato, as reservas cambiais passaram de US\$27,3 bilhões em 1998 para US\$ 267 bilhões em 2007 - devido a uma política agressiva de acumulação de reservas do RBI. Deve-se ressaltar que o aumento das reservas foi em boa medida propiciada pelo aumento nos fluxos de capitais externos, em particular IDE e capitais de portfólio, sendo neste último caso de natureza bem mais volátil. Por outro lado, a razão transações correntes sobre o PIB, que chegou a ser positiva em 2001-2004, voltou a ser negativa a partir de 2005 devido em parte ao crescimento do déficit comercial.

A estratégia e ritmo da liberalização da conta de capital na Índia influenciaram a dimensão e a composição do fluxo de capitais do país (Figura 8). O fluxo de capitais aumentou consideravelmente durante a década de 1990, seguido por uma forte alteração na sua composição: até 1993 houve uma forte predominância de "outros investimentos" (depósitos de não residentes e empréstimos externos); desde 1994, esse fluxo tem aumentado e se diversificado devido ao aumento de investimentos em portfólio, IDEs e outros investimentos. No entanto, a integração financeira da economia indiana ao mercado internacional ainda é pequena e limitada: a relação entre IDE e PIB, em 2002, era de 3,7\% na China, 3,1\% no

\footnotetext{
${ }^{15}$ Por exemplo, os fundos mútuos na Índia agora são autorizados a investir até US\$ 1 bilhão no exterior.

${ }^{16}$ A "regra de bolso" é que patamares seguros para a razão dívida externa sobre exportações encontram-se entre 0 e 2 .
} 
Brasil, 2,1\% no México e apenas $0,6 \%$ na Índia (IMF, 2005, p. 20), mas tem crescido bastante a partir de 2005 em função do crescimento dos investimentos em portfólio e, em menor grau, do IDE. Tais fluxos têm exacerbado as tensões na estrutura da política monetária em função da dificuldade de conciliação entre gerenciamento da taxa de câmbio parcialmente administrada, independência da política monetária e maior abertura financeira. O RBI tem procurado responder tal desafio permitindo uma maior volatilidade na taxa de câmbio e realizando um gerenciamento mais ativo na liquidez, o que, em contexto de abundância de fluxos de capitais externos, tem resultado em uma apreciação na taxa nominal e real do câmbio (Figura 7) ${ }^{17}$.

Figura 8: Índia - fluxo de capitais (obrigações em US\$ milhões)

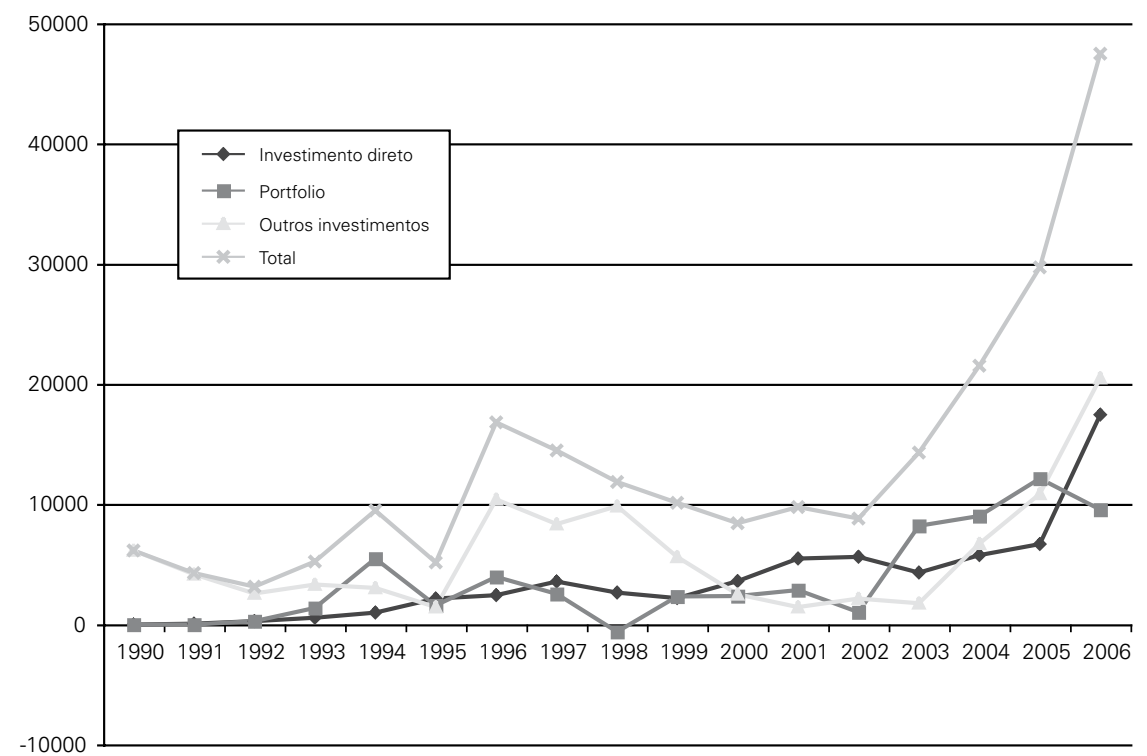

Fonte: IMF

Devido à adoção de um regime de câmbio flutuante administrado, que manteve a taxa de câmbio nominal estável, combinado com elevados déficits fiscais (em função sobretudo de subsídios fiscais ${ }^{18}$ ), a taxa de juros doméstica na Índia

\footnotetext{
${ }^{17}$ Segundo o IMF (2007, p. 15), "os grandes fluxos de capitais estão complicando a condução da política monetária, criando liquidez excessiva e pressionando a rúpia. Intervenção parcialmente esterilizada para suavizar a volatilidade do câmbio tem mantido um largo diferencial na taxa de juros, que por sua vez acentua a entrada de capitais, e assim coloca pressão adicional sobre a taxa de câmbio".

${ }^{18}$ Subsídios ao consumo de querosene para agricultores, ao consumo de energia etc.
} 
apresentou um comportamento oscilante, provavelmente porque foi usada como ferramenta de estabilização da taxa de câmbio e também devido a operações não esterilizadas da política de acúmulo de reservas internacionais, gerando maior volatilidade na base monetária. A Figura 9 mostra uma considerável tendência de queda da taxa de juros após a adoção do regime de câmbio flutuante administrado em 1993. Possivelmente, o controle de capitais na Índia tem sido usado não apenas para reduzir a vulnerabilidade externa e prevenir crises, mas também para introduzir uma "cunha" entre a taxa de juros interna e a internacional, visando proporcionar ao RBI algum grau na condução da política monetária. Finalmente, a inflação vem apresentando uma tendência de queda, resultado da combinação entre liberalização comercial e apreciação recente da taxa de câmbio. Como visto, na Índia os subsídios governamentais têm sido frequentes e visam manter a inflação baixa e estimular a atividade econômica nas pequenas propriedades rurais, ao custo de pressionar o déficit público. O déficit fiscal tem sido relativamente elevado, sendo maior do que 4\% do PIB em 1990-2005 (com uma queda nos anos recentes); a dívida pública em geral tem sido maior que $60 \%$ do $\mathrm{PIB}$, mas sendo denominada em rúpia e com predominância de títulos de longo prazo (IMF, 2005).

Figura 9: Índia - taxa de juros (\% a.a.)

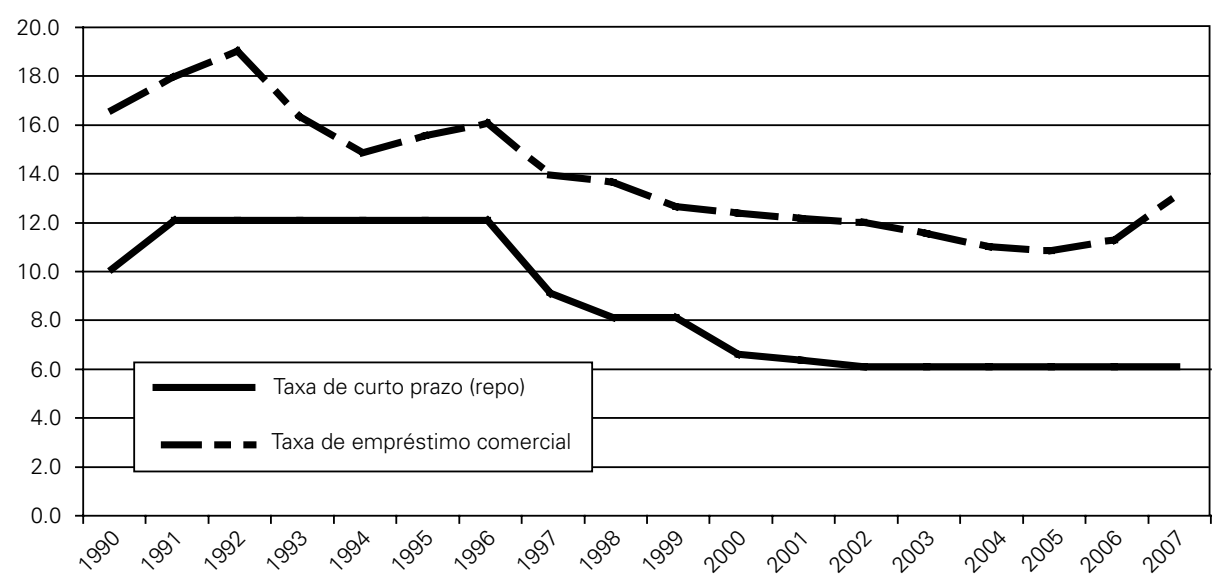

Fonte: $\mathrm{RBI}$

\section{China}

O desempenho da economia chinesa tem sido impressionante: a média do crescimento real do PIB foi de 10\% em 1990-2007, que é praticamente a mesma média do período 1980-1989 (9,8\%), o que significa que por mais de 25 anos o país vem crescendo em média cerca de $10 \%$ ao ano! A principal força motriz dessa expansão econômica tem sido o investimento, cuja taxa cresceu de $25 \%$ do PIB em 1990 para 30\% após 1992 e, desde 2004, está acima de 40\%. Este notável 
desempenho econômico se deve em parte ao rápido crescimento do setor exportador ${ }^{19}$, que permitiu uma notável expansão da China no mercado internacional: a participação do país no comércio mundial cresceu de $0,8 \%$ para $7,7 \%$ entre 1988 e 2005 (Zhao, 2006, p. 4).

A experiência de abertura da economia chinesa tem sido gradual e incremental: as reformas têm sido feitas dentro de um caráter experimental em apenas algumas localidades ou províncias, para só depois serem implementadas em nível nacional. Essas reformas tiveram início no fim da década de 1970: de 1979 a 1986 a política chinesa em relação a IDEs foi marcada pela atitude de que estes seriam bem-vindos desde que fortemente regulados; após 1986 a China deu permissão para operação de empresas $100 \%$ estrangeiras (Haihong, 2000, pp. 19-20). Grandes mudanças foram introduzidas nos anos 1990, de forma a encorajar investimentos estrangeiros, reduzir as tarifas sobre matéria-prima importada, modernizar as empresas estatais, abolir as múltiplas taxas de câmbio e introduzir conversibilidade das transações em conta-corrente.

Tabela 4: China - principais indicadores

\begin{tabular}{|c|c|c|c|c|c|c|c|c|c|}
\hline & 1990 & 1991 & 1992 & 1993 & 1994 & 1995 & 1996 & 1997 & 1998 \\
\hline $\begin{array}{l}\text { Crescimento real } \\
\text { do PIB (\% а.а.) }\end{array}$ & 3,8 & 9,2 & 14,2 & 14,0 & 13,1 & 10,9 & 10,0 & 9,3 & 7,8 \\
\hline $\begin{array}{l}\text { Formaçãa bruta de } \\
\text { capital fixo (\%PIB) }\end{array}$ & 25,0 & 26,9 & 30,9 & 36,0 & 34,5 & 33,0 & 32,4 & 31,8 & 33,0 \\
\hline Inflação (\%а.а.) & 3,1 & 3,5 & 6,3 & 14,6 & 24,2 & 16,9 & 8,3 & 2,8 & $-0,8$ \\
\hline Resultado fiscal (\%PIB) & $-3,7$ & $-3,3$ & $-2,6$ & $-1,9$ & $-1,9$ & $-1,4$ & $-1,2$ & $-1,1$ & $-1,5$ \\
\hline Dívida pública (\%PIB) & n.d. & n.d. & n.d. & n.d. & n.d. & n.d. & n.d. & n.d. & n.d \\
\hline $\begin{array}{l}\text { Taxa de câmbio - média } \\
\text { (RMB/US\$) }\end{array}$ & 4,78 & 5,32 & 5,51 & 5,76 & 8,62 & 8,35 & 8,31 & 8,29 & 8,28 \\
\hline $\begin{array}{l}\text { Reservas cambiais } \\
\text { (excl.ouro, US\$ milhões) }\end{array}$ & 29.586 & 43.674 & 20.620 & 22.387 & 52.914 & 75.377 & 107.039 & 142.762 & 149.188 \\
\hline Conta-corrente (\%PIB) & 3,2 & 3,2 & 1,3 & $-1,8$ & 1,2 & 0,2 & 0,8 & 3,7 & 3,0 \\
\hline $\begin{array}{l}\text { Reservas cambiais } \\
\text { (\% importaçōes) }\end{array}$ & 69,9 & 87,0 & 32,0 & 25,9 & 55,5 & 68,5 & 81,4 & 104,6 & 109,0 \\
\hline Dívida externa (\%PIB) & 14,9 & 14,5 & 15,1 & 13,5 & 16,9 & 15,5 & 14,4 & 14,9 & 13,8 \\
\hline $\begin{array}{l}\text { Dívida externa/ } \\
\text { exportações }\end{array}$ & 1,1 & 1,0 & 1,0 & 1,1 & 1,0 & 0,9 & 0,9 & 0,8 & 0,8 \\
\hline $\begin{array}{l}\text { Dívida de longo prazo } \\
\text { (\% dívida externa) }\end{array}$ & 82,3 & 82,1 & 81,0 & 82,0 & 82,6 & 81,1 & 80,3 & 78,6 & 88,0 \\
\hline $\begin{array}{l}\text { Balança comercial } \\
\text { (US\$ milhões) }\end{array}$ & 9.165 & 8.743 & 5.183 & -10.654 & 7.290 & 18.050 & 19.535 & 46.222 & 46.614 \\
\hline $\begin{array}{l}\text { Conta-corrente } \\
\text { (US\$ milhöes) }\end{array}$ & 11.997 & 13.272 & 6.401 & -11.609 & 6.908 & 1.618 & 7.243 & 36.963 & 31.472 \\
\hline
\end{tabular}

continua na página 723

\footnotetext{
${ }^{19}$ Uma análise econométrica realizada por Vieira (2006), para avaliar o crescimento da China no período de 1970 a 2003, sugere ser a taxa de câmbio e o desempenho das exportações as variáveis mais importantes na explicação do crescimento da economia chinesa.
} 


\begin{tabular}{|c|c|c|c|c|c|c|c|c|c|}
\hline $\begin{array}{l}\text { Crescimento real } \\
\text { do PIB (\% a.a.) }\end{array}$ & 7,6 & 8,4 & 8,3 & 9,1 & 10,0 & 10,1 & 10,4 & 11,6 & 11,9 \\
\hline $\begin{array}{l}\text { Formação bruta de } \\
\text { capital fixo (\%PIB) }\end{array}$ & 33,6 & 34,3 & 34,7 & 36,3 & 39,2 & 40,6 & 41,0 & 40,8 & n.d. \\
\hline Inflação (\%a.a.) & $-1,4$ & 0,3 & 0,5 & $-0,8$ & 1,2 & 3,9 & 1,8 & 1,5 & 4,8 \\
\hline Resultado fiscal (\%PIB) & $-2,2$ & $-2,8$ & $-4,0$ & $-2,6$ & $-2,1$ & $-1,5$ & $-1,3$ & $-1,2$ & n.d. \\
\hline Dívida pública (\%PIB) & n.d. & n.d. & 17,7 & 18,9 & 19,2 & 18,5 & 17,9 & 17,3 & 45,0 \\
\hline $\begin{array}{l}\text { Taxa de câmbio - média } \\
\text { (RMB/US\$) }\end{array}$ & 8,28 & 8,28 & 8,28 & 8,28 & 8,28 & 8,28 & 8,19 & 7,97 & 7,61 \\
\hline $\begin{array}{l}\text { Reservas cambiais } \\
\text { (excl. ouro, US\$ milhões) }\end{array}$ & 157.728 & 168.278 & 215.605 & 291.128 & 408.151 & 614.500 & 821.514 & 1.068 .490 & 1.530 .280 \\
\hline Conta-corrente (\%PIB) & 1,9 & 1,7 & 1,3 & 2,4 & 2,8 & 3,6 & 7,1 & 9,3 & 10,6 \\
\hline $\begin{array}{l}\text { Reservas cambiais } \\
\text { (\% importações) }\end{array}$ & 99,4 & 78,4 & 92,9 & 103,4 & 103,7 & 115,0 & 130,8 & 142,1 & 169,2 \\
\hline Dívida externa (\%PIB) & 14,0 & 12,2 & 8,9 & 12,8 & 12,7 & 12,8 & 12,4 & 11,9 & n.d. \\
\hline $\begin{array}{l}\text { Dívida externa/ } \\
\text { exportações }\end{array}$ & 0,8 & 0,6 & 0,7 & 0,6 & 0,5 & 0,4 & 0,4 & 0,3 & n.d. \\
\hline $\begin{array}{l}\text { Dívida de longo prazo } \\
\text { (\% dívida externa) }\end{array}$ & 90,0 & 91,0 & 69,5 & 64,7 & 57,7 & 53,3 & 47,4 & 46,3 & n.d. \\
\hline $\begin{array}{l}\text { Balança comercial } \\
\text { (US\$ milhões) }\end{array}$ & 35.982 & 34.474 & 34.017 & 44.167 & 44.652 & 58.982 & 134.189 & 217.746 & 315.381 \\
\hline $\begin{array}{l}\text { Conta-corrente } \\
\text { (US\$ milhões) }\end{array}$ & 21.115 & 20.518 & 17.401 & 35.422 & 45.875 & 68.659 & 160.818 & 253.268 & 371.833 \\
\hline
\end{tabular}

Fonte: IMF - International Financial Statistics, Deutsche Bank Research (dívida pública) e ADB - ADB Indicators (dívida externa).

Desde o fim dos anos 1970 o regime cambial mudou algumas vezes: em um primeiro momento ele era centralizado e fixo; de 1986 a 1993 a taxa de câmbio era dual, sendo que a taxa oficial, que era ajustada periodicamente, coexistia com uma taxa determinada no mercado de swap — sendo esta estabelecida em um nível relativamente depreciado em relação à taxa oficial. Em 1994 a taxa oficial foi desvalorizada e unificada com a taxa estabelecida no mercado de swap, e um regime de câmbio flutuante administrado foi oficialmente adotado. Na prática, entretanto, desde 1995, após um breve período de apreciação da taxa de câmbio nominal, a moeda local, o renminbi $(R M B)$, também conhecido como yuan, foi fixado ao dólar (Figura 10). As intervenções do Banco Popular da China (The People's Bank of China - PBC), o banco central chinês, para manter a taxa de câmbio têm sido feitas em larga escala, com as reservas aumentando para mais de $30 \%$ do PIB em 2004. Em julho de 2005, as autoridades chinesas anunciaram uma desvalorização de $2,1 \%$ da taxa de câmbio perante o dólar, com a possibilidade de variação diária dentro de uma banda de $\pm 0,3 \%^{20}$. Além disso, a taxa central para o RMB é determinada por uma cesta de moedas cuja composição não é revelada.

\footnotetext{
${ }^{20}$ Em maio de 2007 essa banda foi aumentada para $\pm 0,5 \%$.
} 
Figura 10: China - TCNE e TCRE (base $2000=100)$

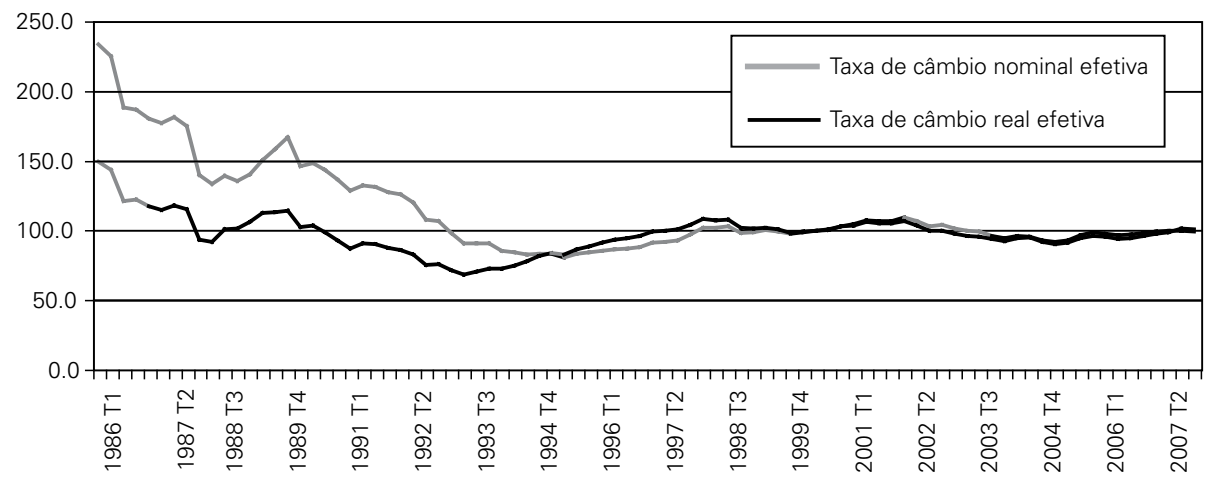

Fonte: IMF e Banco Popular da China

$\mathrm{O}$ PBC age como formador de mercado quando se trata da taxa de câmbio ${ }^{21}$. A administração de uma taxa de câmbio (semi)fixa na China tem sido possível graças a um amplo sistema de controle de capitais tanto na entrada como na saída, usando principalmente proibições e controles quantitativos. Os objetivos desses controles se alteraram ao longo do tempo, mas, de maneira geral, visaram: (i) ajudar a canalizar a poupança externa para a utilização desejada; (ii) manter o política monetária independente da influência do ambiente internacional; (iii) evitar empresas e instituições financeiras de assumirem um risco externo excessivo; (iv) manter a estabilidade da taxa de câmbio; e (iv) isolar a economia dos efeitos de crises financeiras internacionais (Zhao, 2006, p. 8). Assim, a China seguiu um padrão de liberalização financeira que começa com a liberalização das transações comerciais, passa pelo relaxamento das restrições cambiais sobre os fluxos de capital de longo prazo e culmina nos fluxos de capital de curto prazo (Epstein et al., 2003).

Em 1996 a China acatou o Artigo VII do FMI, que determina a liberalização dos controles sobre os fluxos relacionados às transações em conta-corrente. Além disso, desde então os controles sobre o fluxo de capitais de não residentes também têm sido afrouxados, enquanto sobre os residentes eles se mantêm ainda relativamente severos. De fato, no fim de 1996 havia uma série de controles sobre operações cambiais: (i) não residentes estavam proibidos de operar no mercado de moeda, de ações e de derivativos; (ii) residentes só podiam operar nesses mercados com prévia autorização das autoridades monetárias; (iii) necessidade de aprovação prévia de qualquer empréstimo externo ou emissões de títulos em moeda estrangeira (Haihong, 2000). Assim, investimentos em portfólio não eram bem-vindos, devido à segregação entre residentes e não residentes no mercado de ações. Deve-se ressal-

\footnotetext{
${ }^{21}$ A Administração Central da Taxa de Câmbio (ACTC) é responsável por controlar e monitorar o fluxo cambial entre fronteiras e todas as negociações em moeda nacional.
} 
tar a natureza dinâmica dos controles na China, com as autoridades apertando-os em períodos de contágios de crises externas e afrouxando-os no fim delas (Epstein et al., 2003). Mais recentemente, algumas fortes restrições sobre transações cambiais foram amenizadas, enquanto, ao mesmo tempo, algumas tarifas e cotas sobre importações foram reduzidas ou eliminadas ${ }^{22}$.

A taxa de câmbio na China é considerada desvalorizada (Figura 10). A taxa de câmbio real efetiva, baseada no nível de preços ao consumidor, variou muito nos últimos 25 anos: depreciou-se significativamente durante a década de 1980 e no começo dos anos 1990, e apreciou-se por um curto período até 1997, devido ao aumento da inflação. Desde 1997 a taxa de câmbio real efetiva manteve uma trajetória estável, devido aos baixos níveis de inflação e à estabilidade da taxa nominal. $\mathrm{O}$ acentuado processo de acúmulo de reservas na China - que alcançaram a US\$1,5 trilhão em 2007 - teve início no começo dos anos 1990, com um crescimento particularmente maior a partir do ano 2000, resultado de uma política deliberada de acumulação de divisas em contexto de aumento significativo do superávit comercial (de US\$ 34 bilhões em 2001 para US\$ 316 bilhões em 2007) e de elevação da entrada de capitais externos.

Como mostra a Figura 11, houve um elevado crescimento no volume da entrada de capitais externos no país ao longo da década de 1990, devido principalmente ao aumento dos IDEs, de US\$ 4,3 bilhões em 1991 para US\$ 44 bilhões em 1997, vindo a alcançar US\$ 138 bilhões em $2007^{23}$. Esses investimentos têm sido atraídos pela perspectiva de crescimento no longo prazo da economia chinesa (e desempenho das exportações) assim como pelo fato de que, desde o começo das reformas, a China sempre buscou atrair IDEs. Os empréstimos externos, no entanto, tiveram apenas um pequeno crescimento no período, devido à existência de restrições a esse tipo de operação. Assim, ao mesmo tempo em que buscava atrair IDEs, a China agia com cautela em relação a empréstimos externos e investimentos em portfólio, ainda que, recentemente, tais capitais tenham aumentado substancialmente.

\footnotetext{
${ }^{22}$ Em geral, tais medidas reduziram as restrições quantitativas à compra de moeda estrangeira por residentes, relaxando as restrições sobre garantias externas, emissão de títulos no mercado internacional e empréstimos das firmas estrangeiras em RMB.

${ }^{23}$ Uma boa parte desses investimentos é feita por chineses de Taiwan e Hong Kong, o que dá maior estabilidade aos fluxos de capitais externos.
} 
Figura 11: China - fluxo de capitais (obrigações em US\$ milhões)

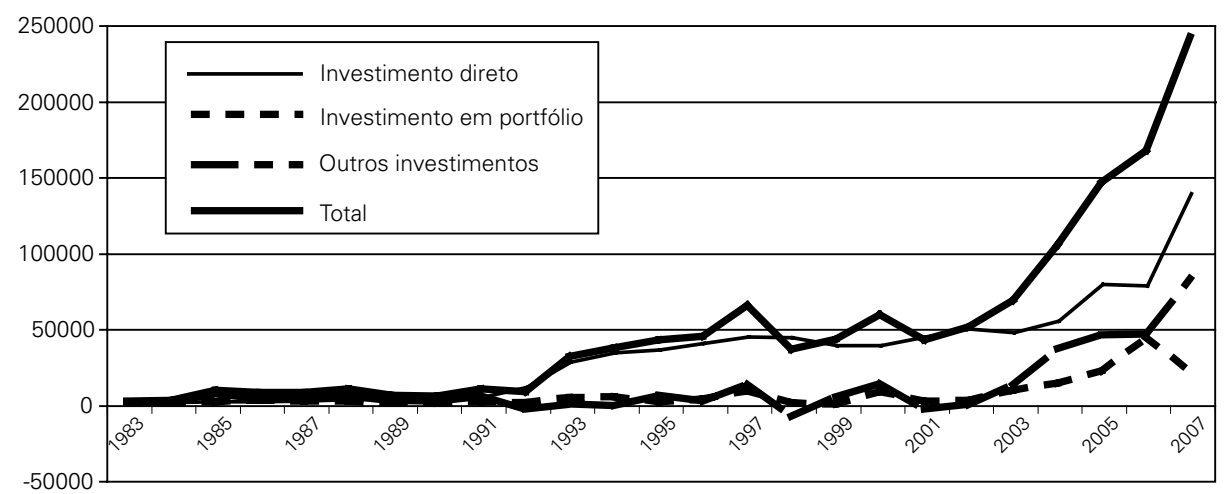

(2009)

Como consequência da combinação entre excepcional superávit comercial, aumento das reservas internacionais e baixo nível de endividamento externo, os indicadores de vulnerabilidade externa da China demonstram uma situação bastante confortável: a relação entre dívida externa e PIB tem sido bastante baixa, normalmente não ultrapassando $15 \%$ do PIB (Tabela 4). Além disso, a participação da dívida de longo prazo sobre o total da dívida externa foi superior a $70 \%$ até 2000; recentemente, essa razão declinou devido ao aumento do endividamento externo, incluindo os de curto prazo. Outros indicadores fornecem mais evidências da boa situação externa: a razão dívida externa sobre exportações - normalmente não superior a 1 , recuou para menos de 0,5 a partir de 2003; a razão entre reservas internacionais sobre importações aumentou de uma média de $54 \%$ entre 1990-1995 para 104\% em 1997 e 170\% em 2007.

Após um curto período e alta inflação e altas taxas de juros na metade da década de 1990, a China experimentou um ambiente de baixas taxas de juros e redução na inflação, incluindo períodos de deflação (Tabela 4 e Figura 12). A combinação entre taxa de câmbio estável, crescimento da produtividade do trabalho, liberalização comercial e queda nos preços das commodities exerceu forte pressão baixista sobre a inflação entre 1996 e $2003^{24}$. A situação fiscal na China se mantém saudável déficits não superiores a 3\% do PIB a partir de 2002 - devido à combinação de forte crescimento econômico e baixas taxas domésticas de juros desde 1999, apesar do resultado primário das contas públicas ser fraco (Prasad et al., 2004). As autoridades chinesas buscam, via esterilização de recursos entrantes, isolar a economia nacional das consequências de uma combinação de taxa de câmbio fixa e grande entrada de capitais, o que tem sido facilitado pelo fato de que a taxa de juros doméstica tem sido menor que a taxa de remuneração dos títulos dos países desenvolvidos.

\footnotetext{
${ }^{24} \mathrm{Em} 2007$ houve um recrudescimento na inflação, que foi de 4,7\% no ano, em boa medida em decorrência do aumento no preço de alimentos.
} 
Figura 12: China - taxa de juros de desconto ( $\%$ a.a)

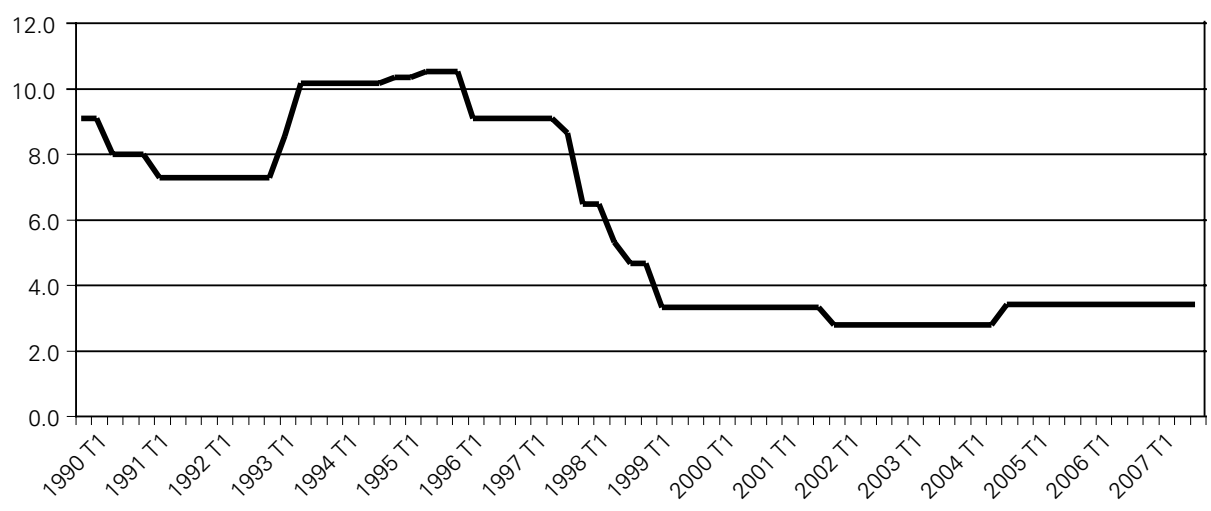

Fonte: IMF

O manejo de uma taxa de câmbio administrada em um contexto de intensa entrada de capitais externos criou constrangimentos para operação da política monetária na China, que as autoridades chinesas enfrentaram com o uso do método de persuasão moral e controles administrativos para conter o crédito (IMF, 2006).

\section{CONCLUSÃO}

China e Índia, administrando seus regimes cambiais e adotando uma conversibilidade parcial da conta capital, tem sido, em diferentes graus, casos de sucesso na gestão da política macroeconômica — onde a estabilidade da taxa de câmbio nominal tem exercido um papel essencial. A experiência de tais países demonstra a eficácia da adoção gradual e cuidadosa de uma administração sobre a conta de capitais e de políticas orientadas para a redução da vulnerabilidade externa. Essas experiências também mostram que controles sobre a conta de capital — inclusive sobre residentes - podem ajudar na proteção da economia contra aspectos desestabilizadores do fluxo de capitais e na solução de certos dilemas política, tal como a administração simultânea da taxa de câmbio e da taxa de juros de curto prazo. A Rússia é um caso interessante, já que a economia, antes de 1998, teve um desempenho muito fraco, como resultado de um caótico processo de transição para uma economia de mercado. No entanto, após a crise de 1998 a economia cresceu consideravelmente, graças ao aumento das exportações e à condução da política macroeconômica, que combinou uma política cambial mais ativa e taxas de juros decrescentes, sob um contexto de conversibilidade parcial da conta capital. Uma fraqueza da economia russa, contudo, é sua dependência das receitas derivadas das exportações de produtos energéticos, fator que contribuiu para ser o país do BRIC que mais sofreu com os impactos da crise financeira internacional de 2008.

O Brasil, por outro lado, adotou uma política econômica mais liberal em relação aos demais países do BRIC, que inclui uma abordagem menos intervencio- 
nista em relação à taxa de câmbio e uma ampla abertura da conta capital, que resultou em maior volatilidade da taxa de câmbio, altas taxas de juros e um crescimento econômico menos acentuado. A economia brasileira, seja no contexto de um regime de câmbio semifixo (1994-1998), seja em um contexto de câmbio flutuante (a partir de 1999), sofreu bastante com os movimentos especulativos contra a sua moeda doméstica. A partir de 2004, favorecido por um contexto internacional benigno, a combinação entre política de acumulação de reservas cambiais, redução da dívida externa pública e superávits comerciais reduziu a vulnerabilidade da economia brasileira, o que permitiu enfrentar a crise de 2008 em melhores condições do que o contágio de outras crises externas.

Entre os diferentes fatores que são importantes na condução da política macroeconômica desses países, esse artigo ressalta em particular importância da redução da vulnerabilidade externa, que deve ser entendida não só em termos de solvência do país, mas também da vulnerabilidade a choques externos. Ademais, a recente experiência do BRIC mostra a importância de se ter (i) um processo gradual e cuidadoso de abertura da conta capital; (ii) técnicas dinâmicas e bem estruturadas de administração do fluxo de capitais, no sentido de que possam ser alteradas de acordo com as circunstâncias; (iii) um superávit na conta de transações correntes ou um pequeno déficit, financiado por capital externo predominantemente de longo prazo; (iv) uma política acúmulo de reservas cambiais por parte do Banco Central, para servir de "escudo" contra ataques especulativos sobre a moeda doméstica; (v) um regime de câmbio flutuante administrado, de acordo com as especificidades de cada país, que busque a preservação de uma taxa real de câmbio competitiva e estável, como um objetivo intermediário de uma política macroeconômica.

\section{REFERÊNCIAS BIBLIOGRÁFICAS}

ADB - ASIAN DEVELOPMENT BANK, ADB Indicators, vários números.

ARIFF, M. e KHALID, A. (2005). Liberalization and Growth in Asia. Cheltenham: Edward Elgar.

ARIYOSHI, A., HABEMEIER, K., LAURENS, B. TKER-ROBE, I., CANALES-KRILJENKO, J. e KIRILENKO, A. (2000). Capital Controls: Country Experiences with Their Use and Liberalization. Washington: IMF.

BRESSER-PEREIRA, L.C. e GALA, P. (2007). "Por que a poupança externa não promove crescimento". Revista de Economia Política 27(1): 3-19.

CALVO, G. e REINHART, C. (2002). "Fear of floating”. Quarterly Journal of Economics, CXVII (2): 379-408.

DEUTSCHE BANK RESEARCH. Disponível em: <http://www.dbresearch.com>. Acesso em: maio de 2009.

EPSTEIN, G., GRABEL, I. e JOMO, K.S. (2003)."Capital management techniques in developing countries". Working Paper Series No. 56, University of Massachusetts.

ESANOV, A., MERKL, C. e VINHAS DE SOUZA, L. (2005). "Monetary policy rules for Russia”. Journal of Comparative Economics, 33(3): 484-499.

FERRARI-FILHO, F. e PAULA, L.F. (2003). "The legacy of the Real Plan and an alternative agenda for the Brazilian economy”. Investigación Económica, LXII (244): 57-92.

FISCHER, S. (2001). "Exchange rate regimes: is the bipolar view correct?" Journal of Economic Perspectives, 15(2): 3-24.

FRENKEL, R. (2006). “An alternative to inflation targeting in Latin America: macroeconomic policies focused on employment”. Journal of Post Keynesian Economics 28(4): 573-591. 
GOLDFAJN, I. e MINELLA, A. (2005). "Capital flows and controls in Brazil: What have we learned?” NBER Working Paper Series No. 11640, Setembro.

GRENVILLE, S. (2000). "Exchange rate regime for emerging countries". Reserve Bank of Australia Bulletin, Novembro.

HABERMEIER, K. (2000). “India's experience with the liberalization of capital flows since 1991". In ARIOYSHI et al. (2000), op. cit.

HAIHONG, G. (2000). "Liberalising China's capital account: lessons drawn from Thailand's experience". Visiting Researchers Series No. 6. Institute of Southeast Asian Studies, Fevereiro.

HO, C. e McCAULEY, R. (2003). "Living with flexible exchange rates: issues and recent experience in inflation targeting emerging market economies". BIS Working Paper No. 130, Fevereiro.

IMF - INTERNATIONAL MONETARY FUND, International Financial Statistics, vários números. . (2001). “India: Recent Economic Developments and Selected Issues”. IMF Country Report No. 01/191, Outubro.

. (2005). "India: Staff Report for the 2004 Article IV Consultation”. IMF Country Report. No. 05/86, Março.

.(2006). "People's Republic of China: 2006 Article IV Consultation”. IMF Country Report. No. 06/394, Outubro.

(2008). “India: 2007 Article IV Consultation”. IMF Country Report. No. 08/51, Fevereiro.

KHOLI, R. (2005). Liberalizing Capital Flows. New Delhi: Oxford University Press.

MOHANTY, M. e SCATIGNA, M. (2005). "Has globalization reduced monetary policy independence?" BIS Papers No. 23, Maio.

MOHANTY, M. e TURNER, P. (2006). "Foreign exchange reserves in emerging countries". BIS Quarterly Review 24: 39-42.

MORENO, R. (2005). "Motives for intervention”. BIS Papers No. 24, Maio.

NAYYAR, D. (2002). "Capital controls and the World Financial Authority: what can we learn from the Indian experience?” In Eatwell, J. e Taylor, L. (ed.). International Capital Markets: Systems in Transition. Oxford: Oxford University Press.

OECD (2006). "Russian Federation”. OECD Economic Surveys vol. 2006/17, Novembro.

OWEN, D. e ROBINSON, D. (ed). (2003). Russia Rebounds. Washington: IMF.

PAULA, L.F. (2011). Financial Liberalization and Economic Performance: Brazil at the Crossroads. Abindgon: Routledge.

PRASAD, E. et al. (2004). "China's growth and integration into the world economy". Occasional Paper No 232. Washington: IMF.

PURUSHOTHAMAN, R. e WILSON, D. (2003). "Dreaming with BRICs: the path to 2050". Global Economics Paper, No. 99, Outubro.

SOUZA, F.E. e HOFF, C.(2006). "O regime cambial brasileiro: 7 anos de flutuação". Disponível em: $<$ http://www.ie.ufrj.br/conjuntura/pdfs/TextoRedeMercosul.pdf>.

VANN DER LAAN, C.R. (2007). Liberalização da Conta de Capitais: Evolução e Evidências para o Caso Brasileiro Recente. Rio de Janeiro: BNDES.

VIEIRA, F.V. "China: crescimento econômico de longo prazo”. Revista de Economia Política, 26(3): 401-424.

WORLD BANK (2007). Russian Economic Report No. 15. Washington: World Bank, Novembro.

WORLD BANK (2008). Russian Economic Report No. 16. Washington: World Bank, Junho.

ZHAO, M. (2006). "External liberalization and the evolution of China's exchange system". The World Bank Beijing Office. 